\title{
Fluxes of particulate organic carbon in the East China Sea in
}

\section{summer}

\author{
C.-C. Hung ${ }^{1,2}$, C.-W. Tseng ${ }^{3}$, G.-C. Gong ${ }^{2,3}$, K.-S. Chen ${ }^{1}$, M.-H. Chen ${ }^{1}$, and S.-C. Hsu ${ }^{4}$ \\ ${ }^{1}$ Department of Oceanography, and Asia-Pacific Ocean Research Center, National Sun Yat-sen University, Kaohsiung 804, \\ Taiwan \\ ${ }^{2}$ Taiwan Ocean Research Institute, National Applied Research Laboratories, Kaohsiung 852, Taiwan \\ ${ }^{3}$ Institute of Marine Environmental Chemistry and Ecology, and Center of Excellence for the Oceans, National Taiwan Ocean \\ University, Keelung 202, Taiwan \\ ${ }^{4}$ Research Center for Environmental Changes, Academia Sinica, Taipei 115, Taiwan
}

Correspondence to: C.-C. Hung (cchung@mail.nsysu.edu.tw)

Received: 27 December 2012 - Published in Biogeosciences Discuss.: 5 March 2013

Revised: 28 August 2013 - Accepted: 2 September 2013 - Published: 11 October 2013

\begin{abstract}
To understand carbon cycling in marginal seas better, particulate organic carbon (POC) concentrations, POC fluxes and primary production (PP) were measured in the East China Sea (ECS) in summer 2007. Higher concentrations of POC were observed in the inner shelf, and lower POC values were found in the outer shelf. Similar to POC concentrations, elevated uncorrected POC fluxes (720-7300 $\mathrm{mg} \mathrm{C} \mathrm{m}^{-2} \mathrm{~d}^{-1}$ ) were found in the inner shelf, and lower POC fluxes $\left(80-150 \mathrm{mg} \mathrm{C} \mathrm{m}^{-2} \mathrm{~d}^{-1}\right)$ were in the outer shelf, respectively. PP values $\left(\sim 340-3380 \mathrm{mg} \mathrm{C} \mathrm{m}^{-2} \mathrm{~d}^{-1}\right)$ had analogous distribution patterns to POC fluxes, while some of PP values were significantly lower than POC fluxes, suggesting that contributions of resuspended particles to POC fluxes need to be appropriately corrected. A vertical mixing model was used to correct effects of bottom sediment resuspension, and the lowest and highest corrected POC fluxes were in the outer shelf $\left(58 \pm 33 \mathrm{mg} \mathrm{C} \mathrm{m}^{-2} \mathrm{~d}^{-1}\right)$ and the inner shelf $\left(785 \pm 438 \mathrm{mg} \mathrm{C} \mathrm{m}^{-2} \mathrm{~d}^{-1}\right)$, respectively. The corrected POC fluxes (486 to $785 \mathrm{mg} \mathrm{C} \mathrm{m}^{-2} \mathrm{~d}^{-1}$ ) in the inner shelf could be the minimum value because we could not exactly distinguish the effect of POC flux from Changiiang influence with turbid waters. The results suggest that 27$93 \%$ of the POC flux in the ECS might be from the contribution of resuspension of bottom sediments rather than from the actual biogenic carbon sinking flux. While the vertical mixing model is not a perfect model to solve sediment resuspension because it ignores biological degradation of sinking particles, Changjiang plume (or terrestrial) inputs and lateral
\end{abstract}

transport, it makes significant progress in both correcting the resuspension problem and in assessing a reasonable quantitative estimate of POC flux in a marginal sea.

\section{Introduction}

Continental margins only account for $8 \%$ of the surface area of the ocean, but they contribute approximately $30 \%$ of global primary production (Liu et al., 2000). Walsh (1989) proposed that continental shelf regimes were an important organic carbon source to the open ocean because marginal seas have elevated phytoplankton primary production and higher particulate organic carbon (POC) inventories as compared to those in the open ocean. Thus, marginal seas are believed to influence marine carbon biogeochemical cycling and fishery crucially (Liu et al., 2010, and references therein; Chou et al., 2009a, b, 2011; Gong et al., 2011). Indeed, one of the major objectives of the international research project Land-Ocean Interaction in the Coastal Zone (LOICZ) is to quantify the exchange of carbon between continental shelves, marginal seas, and the open ocean.

The East China Sea (ECS) is among the largest marginal seas on the earth and has a high primary production $(0.3$ to $1.5 \mathrm{~g} \mathrm{C} \mathrm{m}^{-2} \mathrm{~d}^{-1}$ ) in coastal areas, particularly during the summer months (Gong et al., 2003). According to previous reports, the ECS has been regarded as an important sink $\left(10-30 \mathrm{MtC} \mathrm{yr}^{-1}, 1 \mathrm{Mt}=10^{12} \mathrm{~g}\right)$ of atmospheric $\mathrm{CO}_{2}$ based 
on measurements of $\mathrm{CO}_{2}$ air-sea exchange (Tsunogai et al., 1999; Peng et al., 1999; Wang et al., 2000; Shim et al., 2007; Chou et al., 2013). Model-estimated organic carbon burial on the broad ECS shelf was 7-10 MtC yr ${ }^{-1}$ (Chen and Wang, 1999), and the estimated burial organic carbon transported offshore was from 2 to $12 \mathrm{Mt} \mathrm{C} \mathrm{yr}^{-1}$ (Liu et al., 2006, 2010). While these estimations show large uncertainties, the net imbalance of organic carbon fluxes in the ECS amounts to approximately $10-20 \mathrm{MtC} \mathrm{yr}^{-1}$. Although fluxes of particles and POC have been estimated in the ECS and adjacent areas (Hung et al., 1999, 2003; Hoshika et al., 2003; Oguri et al., 2003; Iseki et al., 2003; Guo and Zhang, 2005; Zhu et al., 2006; Hung and Gong, 2011), direct measurements of POC fluxes in the ECS coastal region are very limited (Iseki et al., 2003; Guo et al., 2010).

There is no simple means to estimate POC fluxes in the marginal seas due to strong sediment resuspension, lateral transport or dense shelf water cascading, although several methods (carbon budget, vertical flux and box model) have been used (Smith and Hollibaugh, 1993; Falkowski et al., 1994; Oguri et al., 2003; Hoshika et al., 2003). Most importantly, recent studies have shown that POC fluxes (measured by moored sediment traps, 300-5000 $\mathrm{mg} \mathrm{C} \mathrm{m}^{-2} \mathrm{~d}^{-1}$, Iseki et al., 2003) were sometimes higher than PP in the ECS (500-2500 $\mathrm{mg} \mathrm{C} \mathrm{m}^{-2} \mathrm{~d}^{-1}$, Gong et al., 2003, 2006; Liu et al., 2010). Iseki et al. (2003) suggested that elevated POC fluxes could be downslope transport of resuspended particles. As mentioned above, the ECS has the highest PP during the summer (Gong et al., 2003, 2006). Therefore, possible factors resulting in POC fluxes being higher than PP could be sediment resuspension, fluvial particles or lateral transport because dense shelf water cascading (mainly happens in winter) in summer is unlikely in this case. To exclude resuspended POC of the sediments better in the marginal seas, we measured POC concentrations and fluxes and used a vertical end-member mixing model to calibrate the POC flux appropriately. Additionally, we also measured PP to constrain the corrected POC flux in the ECS

\section{Sampling and analytical methods}

Seawater samples (32 stations) were collected aboard the R/V Ocean Researcher I in the ECS from 1 to 11 July 2007 (Fig. 1). Temperature was recorded using a SeaBird model SBE9/11 plus conductivity-temperature-depth (CTD) recorder, and salinity was determined with an Autosal salinometer. Transmissometer (C-Star, Wet Lab, USA) data (TM $\%)$ were recorded by the transmissometer attached to the CTD. Seawater samples were collected using $20 \mathrm{~L}$ X-Niskin bottles (General Oceanic Inc. USA) from different depths $(2,5,10,15,20,25,30,40,50,60,70,90,110,150 \mathrm{~m})$ for measurements of chlorophyll $a(\mathrm{Chl} a)$ and POC concentrations. The Chl $a$ samples were collected by filtering $1180 \mathrm{~mL}$ of seawater at inner shelf and $2030 \mathrm{~mL}$ for other

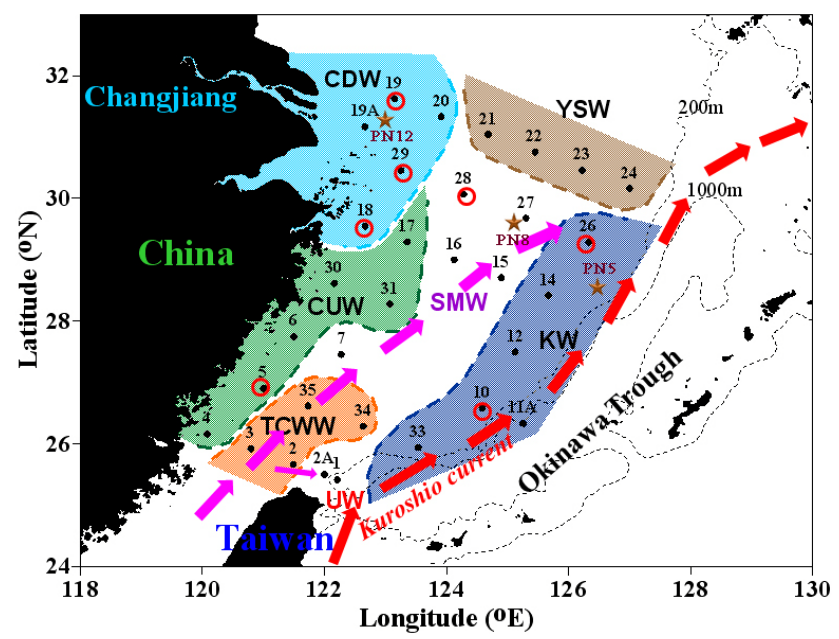

Fig. 1. Sampling locations (black dots) and hydrography in the East China Sea. The dashed band with red arrows represents the main stream of the Kuroshio Current, and the pink arrows represent the Taiwan Warm Current in summer. Red circles indicate the surface sediment stations and the sediment trap deployment stations in summer 2007. CDW: Changjiang diluted water, YSW: Yellow Sea water, CUW: coastal upwelling water, TCWW: Taiwan Current warm water, UW: Kuroshio upwelling water, KW: Kuroshio water, SMW: shelf mixing water (mixing of a major CDW and a minor of CUW + YSW + TCWW), after Liu et al. (2000), Kao et al. (2003), and Chou et al. (2009a, b).

stations through a GF/F filter (pore size $=0.7 \mu \mathrm{m}$ ) and stored at $-20^{\circ} \mathrm{C}$ until analysis. Top surface sediment samples $(0-$ $2 \mathrm{~cm}$ ) at sediment trap stations (e.g., stations S18, S19, S28, S29, S5, S10, and S26) were collected using a box-core sampler (Fig. 1). The sediment samples were then transferred to the laboratory and frozen $\left(-20^{\circ} \mathrm{C}\right)$ until analysis. Briefly, freeze-dried sediment sub-samples were first heated at $60^{\circ} \mathrm{C}$ and treated (2-3 treatments) with $2 \mathrm{~N} \mathrm{HCl}$ to remove inorganic carbon. POC concentrations were determined using an elemental analyzer (Elementa, Germany) (Hung et al., 2009a).

Concentration of Chl $a$ on the GF/F filter was determined according to standard procedures using a Turner Designs 10AU-005 fluorometer by the non-acidification method (Gong et al., 2000). The filters were ground in and extracted with $10 \mathrm{~mL}$ of $90 \%$ acetone at $4{ }^{\circ} \mathrm{C}$ for $2 \mathrm{~h}$ under low light conditions. Then, the mixture was centrifuged for $10 \mathrm{~min}$ at $3000 \mathrm{rpm}$. The concentration of Chl $a$ in the supernatant liquid was measured fluorometrically with a fluorometer. The precision in the determination of $\mathrm{Chl} a$ is approximately $\pm 7 \%$ at $0.1 \mathrm{mg} \mathrm{m}^{-3}$. The detection limit of $\mathrm{Chl} a$ is $0.1 \mu \mathrm{g} \mathrm{Chl} a \mathrm{~L}^{-1}$. Sub-samples $(0.5-2 \mathrm{~L}$ for the inner and middle shelves and 4-6L for the outer shelf) for total suspended matter (TSM) were filtered through pre-weight GF/F filters (after pre-combusted at $500^{\circ} \mathrm{C}$ for $6 \mathrm{~h}$ ) and then rinsed with about $20 \mathrm{~mL}$ of Milli-Q water. The analytical uncertainty (one sigma error) for TSM was approximately $5-10 \%$ 
Table 1. Parameters of bottom depth, euphotic zone (EZ) depth, uncorrected POC flux, and primary production (PP) in the ECS.

\begin{tabular}{llccccc}
\hline $\begin{array}{l}\text { Water } \\
\text { mass }\end{array}$ & Station & $\begin{array}{c}\text { Bottom depth } \\
(\mathrm{m})\end{array}$ & $\begin{array}{c}\text { EZ } \\
(\mathrm{m})\end{array}$ & $\begin{array}{c}\text { Trap depth } \\
(\mathrm{m})\end{array}$ & $\begin{array}{c}\text { Uncorr. POC flux } \\
\left(\mathrm{mg} \mathrm{C} \mathrm{m}^{-2} \mathrm{~d}^{-1}\right)\end{array}$ & $\begin{array}{c}\text { PP } \\
\left(\mathrm{mg} \mathrm{C} \mathrm{m}^{-2} \mathrm{~d}^{-1}\right)\end{array}$ \\
\hline CDW & S18 & 47 & 15 & 20 & 3900 & 1897 \\
CDW & S19 & 38 & 22 & 20 & 7300 & 3045 \\
SMW & S28 & 60 & 50 & 30 & 200 & 600 \\
CDW & S29 & 57 & 26 & 20 & 750 & 3377 \\
CUW & S5 & 51 & 36 & 20 & 720 & 337 \\
KW & S10 & 154 & 90 & 120 & 80 & 1153 \\
KW & S26 & 118 & 74 & 100 & 150 & 442 \\
\hline
\end{tabular}

as estimated from duplicate measurements. A few of TSM values in the outer shelf were derived according to the relationship between TSM and TM \% due to possible salt effect.

After measuring TSM concentrations, these GF/F filters were used to determine POC concentrations (Hung et al., 2010a, 2011). Sinking particles (7 stations) were collected at $20 \mathrm{~m}(\mathrm{~S} 18, \mathrm{~S} 19, \mathrm{~S} 29, \mathrm{~S} 5)$ (inner shelf region), $30 \mathrm{~m}$ (S28) (middle shelf region), $100 \mathrm{~m}$ (S26) and $120 \mathrm{~m}$ (S10) (outer shelf region) (Fig. 1 and Table 1) by a drifting sediment trap array, which consisted of six $6.8 \mathrm{~cm}$ diameter cylindrical plastic core tubes with honeycomb baffles covering the trap mouths (Santschi et al., 2003; Hung et al., 2009a, 2010b). The array was attached to an electric surface buoy with a global positioning system (GPS) antenna (TGB-500, TAIYO, Japan). The trap tubes, filled with filtered seawater (sparkling clear polypropylene filter, nominal size $0.5 \mu \mathrm{m}$ ), were deployed for short-scale deployment (3-8h) due to intensive fishery activity. Sinking particles were filtered through precombusted $\left(500^{\circ} \mathrm{C}, 6 \mathrm{~h}\right)$ quartz filters (Whatman QMA, pore size $=1.0 \mu \mathrm{m}$ ). The swimmers caught on the filters were observed using a microscope and carefully removed using forceps. In brief, carbonate carbon on the filter was fumed overnight by concentrated $\mathrm{HCl}$ in a vacuum desiccator and then dried at $50^{\circ} \mathrm{C}$ in an oven. POC concentrations in both suspended and sinking particles were measured using an elemental analyzer after filters were $\mathrm{HCl}$-fumed.

The precision in the determination of POC is approximately $\pm 2 \%$ at $20 \mu \mathrm{g} \mathrm{CL}^{-1}$. The detection limit of POC is $5 \mu \mathrm{g} \mathrm{C} \mathrm{L}{ }^{-1}$. Selected samples contained two quartz filters; the second was treated as a POC blank ranging from 0.8 to $2.0 \mu \mathrm{mol}$ per $25 \mathrm{~mm}$ quartz filter. The POC flux was extrapolated to $24 \mathrm{~h}$ (=1 day) on the assumption that the POC flux at night was the same as that during the day. We thus feel confident that diurnal variability in POC fluxes, if it exists, is small compared to other sources of error in our measurements. Trapping efficiency of the floating sediment traps in the ECS and the oligotrophic water, based on the ${ }^{234} \mathrm{Th} /{ }^{238} \mathrm{U}$ disequilibrium model of Hung et al. (2004), ranged between $75 \%$ (Li, 2009) and $80 \%$ (Hung and Gong, 2007), respectively. Concentrations of rare earth elements in the sinking particles were processed by the total digestion method us- ing mixed acids of Suprapur $\mathrm{HF}, \mathrm{HNO}_{3}$ and $\mathrm{HClO}_{4}$ (all from Merck, Germany) and measured by the quadrupole-based inductively coupled plasma mass spectrometer (ICP-MS, Elan 6100 , Perkin-Elmer Instruments, USA). The detailed procedure has been given elsewhere (Hsu and Lin, 2010).

Primary production (PP) was determined by the ${ }^{14} \mathrm{C}$ assimilation method (Parsons et al., 1984; Hung et al., 2000; Gong et al., 2003). Briefly, water samples for the PP measurements were pre-screened through a $200 \mu \mathrm{m}$ mesh and dispensed into acid-cleaned polycarbonate carboy $(10 \mathrm{~L}$, Nalgene). Each subsample was inoculated with $10 \mu \mathrm{Ci}$ $\mathrm{NaH}^{14} \mathrm{CO}_{3}$ before incubation. The $\mathrm{P}^{\mathrm{B}}-\mathrm{E}$ (photosyntheticirradiance) curve at each sampling depth was determined using a seawater-cooled incubator illuminated for two hours with artificial light. PP at each depth could then be calculated with the parameters from the $\mathrm{P}^{\mathrm{B}}$-E curve. The euphotic zone integrated primary production (IP) was calculated using a trapezoid rule. The detailed procedures can be found in Gong et al. (2003).

\section{Results}

\subsection{Hydrographic settings and distributions of $\mathrm{Chl} a$, POC and TSM in the ECS}

Surface waters were grouped into seven categories: (1) KW (the Kuroshio water), (2) TCWW (the Taiwan Current warm water), (3) CDW (the Changjiang diluted water), (4) YSW (the Yellow Sea water), (5) CUW (the coastal upwelling water), (6) SMW (shelf mixing water of CDW and CUW+YSW+TCWW), and (7) UW (Kuroshio upwelling water). The distributions of various water types during the study period are shown in Fig. 1. KW primarily occurred in the southeast corner; TCWW was present mainly in the middle shelf of the ECS; CDW was confined mainly to the northwest corner; YSW occurred in the northeast; CUW was present along the coast (not including station 5) of mainland China beyond the influence of CDW, and south of the YSW area the surface waters of the middle shelf were TCWW + YSW (stations 15, 16, 27, and 28). The CDW + CUW water type (station 30) occurred at the 

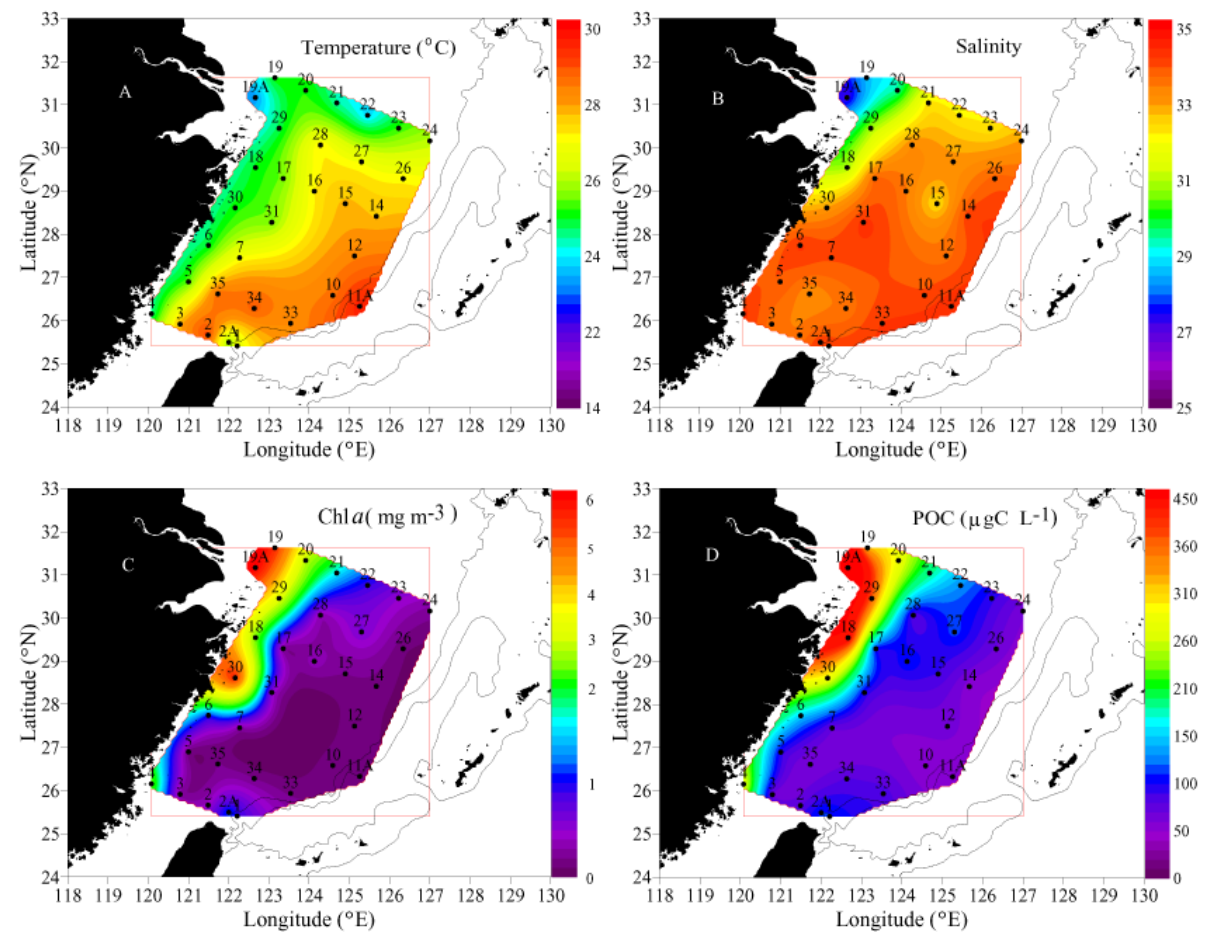

Fig. 2. Contours of surface temperature (A), salinity (B), chlorophyll (Chl $a$ ) concentration $(\mathbf{C})$ and POC concentration (D) in the East China Sea in summer 2007, respectively.

boundary between CDW and CUW. This distribution of water types is generally consistent with the known summer circulation pattern in the ECS (Fig. 1) (Lee and Chao, 2003).

The surface distributions of temperature, salinity, Chl $a$ concentration and POC concentrations in the ECS in July 2007 are shown in Fig. 2a-d. Sea surface temperatures (SST) at all stations were above $23^{\circ} \mathrm{C}$ with lower SST in the coastal and inner shelf regions and higher SST in the outer shelf (Fig. 2a). Surface salinity gradually increased from the coastal area toward the shelf edge (Fig. 2b). Distributions of surface $\mathrm{Chl} a$ concentrations ranged from 0.3 to $8.9 \mathrm{mg} \mathrm{m}^{-3}$. Chl $a$ concentrations in the outer shelf were low and increased moving landward towards the Chinese coast and the Changjiang Estuary (Fig. 2c), becoming the highest $\left(>5 \mathrm{mg} \mathrm{m}^{-3}\right)$ in the Changjiang diluted water (CDW). The higher Chl $a$ was supported by nutrient-rich water (Gong et al., 2006; Hung et al., 2010b). Distributions of surface POC concentrations varied between 40 and $450 \mu \mathrm{g} \mathrm{L}^{-1}$ in the ECS. High concentrations $\left(200-450 \mu \mathrm{g} \mathrm{L}^{-1}\right)$ of POC were observed in coastal surface waters (e.g., CDW, S19, S19A, S29 and S18), followed by the middle shelf $\left(80-160 \mu \mathrm{g} \mathrm{L}^{-1}\right)$, and generally decreased towards the shelf, with the lowest values (40-70 $\mu \mathrm{g} \mathrm{L}^{-1}$ ) found in the outer shelf (Fig. 2d) with the exception high POC values $\left(72-140 \mu \mathrm{g} \mathrm{L}^{-1}\right)$ in the southern ECS (e.g., stations 1 and 2A).

Vertical distributions of $\mathrm{Chl} a$, POC and TSM concentrations in the inner and middle shelves (e.g., S18, S19, S29,
S5, S28) and outer shelf (e.g., S10 and S26) are shown in Fig. 3a-f, respectively. In the inner shelf (e.g., stations 18, 19 and 29), elevated Chl $a$ concentrations $\left(2-5 \mathrm{mg} \mathrm{m}^{-3}\right.$ ) were apparent in the surface layer. In contrast to the high Chl $a$ concentration in the inner shelf (e.g., stations 10 and 26), the outer shelf had low phytoplankton biomass (surface Chl $a$ concentration $<0.4 \mathrm{mg} \mathrm{m}^{-3}$ ) (Fig. 3a and b). An interesting feature is that at stations 5, 10, 26 and 28, maximum Chl $a$ concentrations were always observed above the depth of the euphotic zone (Table 1) and decreased with increasing depth. Elevated POC concentrations were generally observed near surface or subsurface waters and decreased with water depth at most stations in the inner and middle shelves (Fig. 3c and d).

\subsection{Relationships between POC and Chl $a$ (TSM) and $\mathrm{C} / \mathrm{N}$ ratios in the ECS}

Concentrations of POC and Chl $a$ showed a strong positive correlation in the ECS (Fig. 4a), suggesting that the production of POC might be affected by the phytoplankton activity. Our POC/Chl $a$ value $\left(64 \mathrm{gg}^{-1}\right)$ is in agreement with previous investigations in the northern East China Sea and the Gulf of Mexico (13-94 $\mathrm{gg}^{-1}$, Chang et al., 2003; $70 \mathrm{~g} \mathrm{~g}^{-1}$, Hung et al., 2009b). A good correlation ( $\mathrm{POC} / \mathrm{TSM}=0.93 \mu \mathrm{mol} \mathrm{mg}{ }^{-1}$ ) between POC and TSM (except for data marked by the blue circle) was also observed, as shown in Fig. 4B. Zhu et al. (2006) also reported a similar 

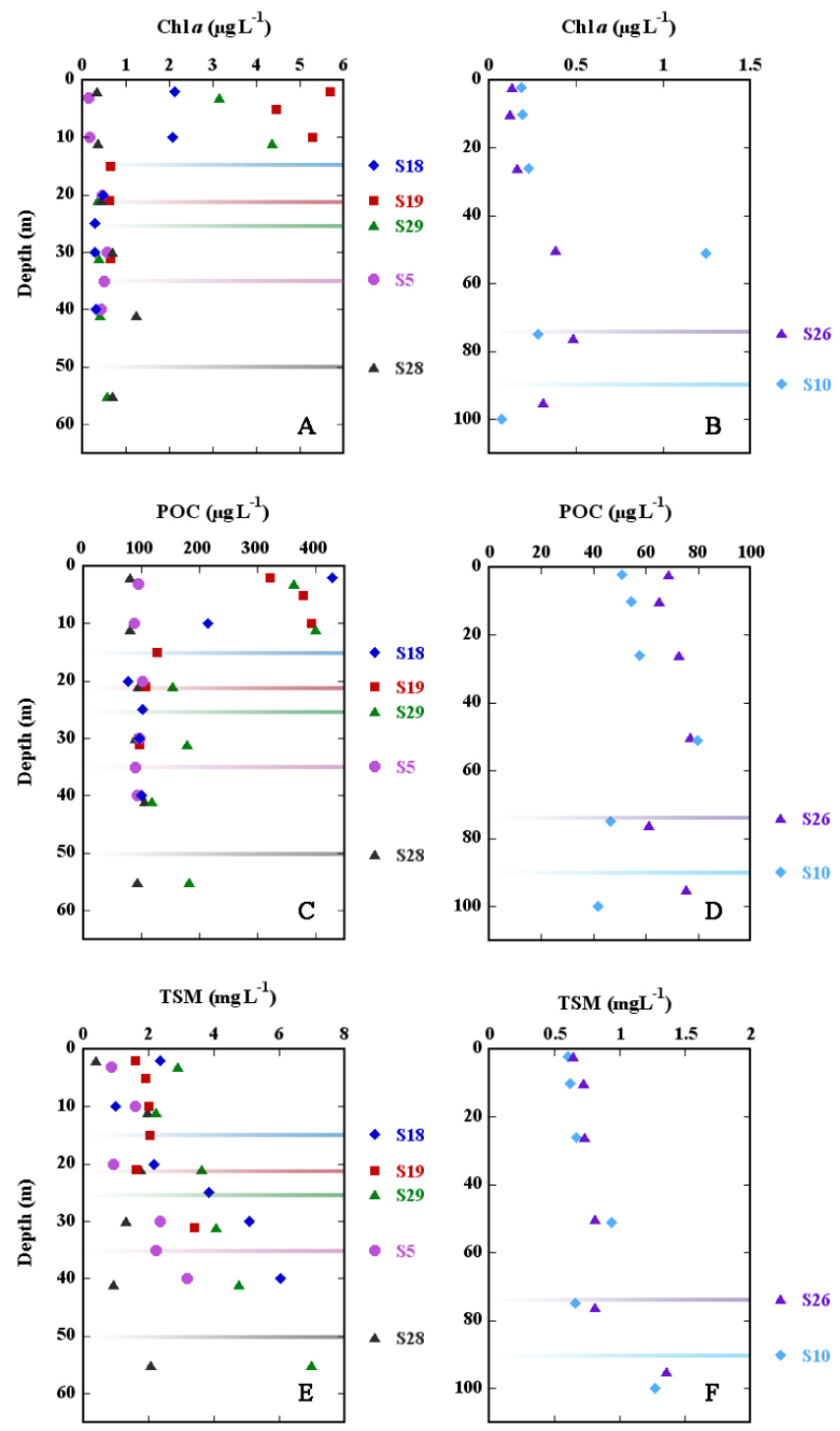

Fig. 3. Distributions of vertical Chl $a$ (A and B), POC concentrations ( $\mathbf{C}$ and $\mathbf{D})$ and total suspended matter (TSM) concentrations (E and F) in the inner shelf (S18, S19, S29, S5, and S28) and the outer shelf (S10 and S26) of the East China Sea. The different color lines indicate the depths of the euphotic zone at stations (S18, S19, S29, S5, S28, S26 and S10).

positive relationship ( $\mathrm{POC} / \mathrm{TSM}=0.74 \mu \mathrm{mol} \mathrm{mg}^{-1}$ ) between POC and TSM in the inner shelf of the ECS in October and November, but they did not find a good relationship between POC and TSM in the middle shelf. Moreover, a significant correlation between POC and particulate nitrogen (PN) was obtained, as shown in Fig. 4c, where the slope is approximately 5.9, close to Redfield ratios suggesting a marine biogenic source of the particles. Figure 4d shows a good relationship (some data away from the correlation line) between POC/TSM and the reciprocal of TSM suggesting that the constituents of TSM are a mixture of two end-members: one consisting of high POC content and low TSM, and the other consisting of low POC content and high TSM.

\subsection{Spatial variation of uncorrected POC fluxes and PP in the ECS}

Uncorrected elevated POC fluxes (720-7300 $\mathrm{mg} \mathrm{C} \mathrm{m}^{-2} \mathrm{~d}^{-1}$ ) during the summer found in the inner shelf (trap depths about $18-27 \mathrm{~m}$ above the bottom) stations S5, S18, S19, and S29 were 720, 3900, 7300 and $750 \mathrm{mg} \mathrm{C} \mathrm{m}^{-2} \mathrm{~d}^{-1}$, respectively. Uncorrected high POC flux in the inner shelf gradually decreased towards the middle shelf station S28 (trap depth about $30 \mathrm{~m}$ above the bottom) approximately $200 \mathrm{mg} \mathrm{C} \mathrm{m}^{-2} \mathrm{~d}^{-1}$, and then the outer shelf stations $\mathrm{S} 10$ (80 $\mathrm{mg} \mathrm{C} \mathrm{m}^{-2} \mathrm{~d}^{-1}$ ) and $\mathrm{S} 26$ (150 $\mathrm{mg} \mathrm{C} \mathrm{m}^{-2} \mathrm{~d}^{-1}$ ) (trap depth about $18-34 \mathrm{~m}$ about the bottom), respectively (Table 1 ). Iseki et al. (2003) reported that seasonal POC fluxes (100-3000 $\mathrm{mg} \mathrm{C} \mathrm{m}^{-2} \mathrm{~d}^{-1}$ ) in the inner shelf (e.g., station PN 12, marked in Fig. 1) of the ECS with the highest value occurring in the bottom turbid layer ( $\sim 5$ to $30 \mathrm{~m}$ above the bottom) in winter (February to March) and fall (October), and the lowest value in spring. However, Iseki et al. (2003) did not have summer POC flux data in the inner shelf of the ECS. Iseki et al. (2003) also found that high POC fluxes ( 50-4000 $\mathrm{mg} \mathrm{C} \mathrm{m}^{-2} \mathrm{~d}^{-1}$ ) appear at the bottom turbid layer in the middle (e.g., station PN8, the moored trap depths were approximately 5 to $40 \mathrm{~m}$ above the bottom, Fig. 1) shelf of the ECS with the highest POC flux in summer (August). In the outer shelf (e.g., station PN5, the moored trap depths were approximately 5 to $80 \mathrm{~m}$ above the bottom, Fig. 1), the POC flux ranged from $\sim 30$ to $\sim 1100 \mathrm{mg} \mathrm{C} \mathrm{m}^{-2} \mathrm{~d}^{-1}$ with the highest value in winter and fall (Iseki et al., 2003). In comparison, the uncorrected POC flux in the middle shelf in summer is much lower than the value reported by Iseki et al. (2003). However, the uncorrected POC flux in the outer shelf in summer is similar to the value reported by Iseki et al. (2003).

Distribution of PP in the ECS is similar to uncorrected POC flux pattern with higher PP (1897-3377 $\mathrm{mg} \mathrm{C} \mathrm{m}^{-2} \mathrm{~d}^{-1}$ ) in the inner shelf (S18, S19 and S29, except for S5 with $\mathrm{PP} \sim 337 \mathrm{mg} \mathrm{C} \mathrm{m}^{-2} \mathrm{~d}^{-1}$ ) and lower PP (440$1153 \mathrm{mg} \mathrm{C} \mathrm{m}^{-2} \mathrm{~d}^{-1}$ ) in the outer shelf (S10 and S26). Gong et al. (2003) reported that PP showed intensive seasonal variation in the ECS with the highest value ( $>2000 \mathrm{mg} \mathrm{C} \mathrm{m}^{-2} \mathrm{~d}^{-1}$ ) in the inner shelf in summer approximately three-fold higher than that in other seasons. In comparison, most of measured PP values in this study were analogous to previously PP reported by Gong et al. (2003) and Liu et al. (2010). Overall, one may see that some of POC fluxes in the inner shelf are significantly higher than PP (Table 1) suggesting that Changjiang might bring high fluvial suspended particles, or some of POC fluxes were re-counted due to resuspended particulate matter. Therefore, in the later section, we will use a vertical mixing model to exclude the 

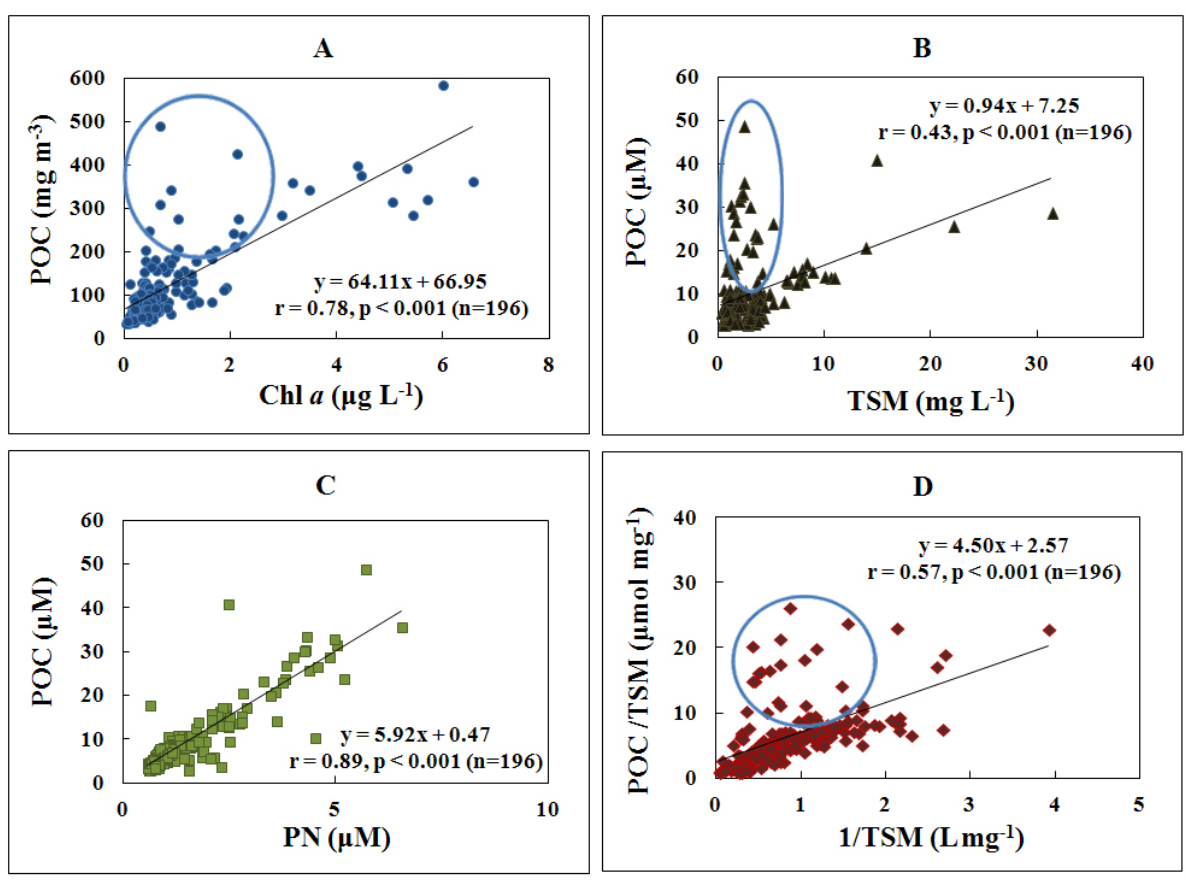

Fig. 4. Relationships between POC and Chl $a$ (A); POC and TSM (B); POC and PN (C); POC/TSM and 1/TSM (D) in the ECS.

possible influences from resuspended particulate matter from the surface sediments.

\subsection{Using a vertical particle mixing model to correct POC flux}

As mentioned above, some of uncorrected POC fluxes were much higher than those of primary production, suggesting that bottom sediment resuspension could be likely associated with the elevated POC fluxes in the ECS. First, we used a vertical particle mixing model derived by Morris et al. (1987) to obtain two end-member values: one with high POC content and low total suspended matter (TSM), and the other with low POC content and high TSM (Bloesch, 1994). The two end-member mixing model is shown in Eq. (1) (Bale and Morris, 1998).

$C=\left(S_{\mathrm{o}}\left(C_{\mathrm{o}}-C_{\mathrm{s}}\right)\right) / S+C_{\mathrm{s}}$,

where $C$ is the observed POC concentration (\%) in the mixture, $S_{\mathrm{o}}$ the total weight of surface phytoplankton $\left(\mathrm{mg} \mathrm{L}^{-1}\right)$, $S$ the total weight of observed suspended particles $\left(\mathrm{mg} \mathrm{L}^{-1}\right)$, $C_{\mathrm{o}}$ the POC concentration of phytoplankton (\%), and $C_{\mathrm{s}}$ the POC concentration of surface sediment (\%). The data of $C_{\mathrm{s}}$ and $C_{\mathrm{o}}$ can be obtained according to the observed parameters $C$ and $S$ by plotting suspended POC concentrations against the reciprocal of observed suspended particle concentration, TSM (Fig. 5). It is noted that SMW (shelf mixing water) was composed of CDW (major) and YSW + TCWW (minor) so that we used the values of the slope obtained for CDW at station 28.
Linear relationships between POC and TSM in the CDW, CUW and KW all show significant correlations with low $p$ values $(<0.001$, Fig. 5), suggesting that POC content is mainly controlled by the mixing of two end-members, thus attesting to the utility of this mixing model (Morris et al., 1987; Bale and Morris, 1998). The slope in Fig. 5 is equal to $S_{\mathrm{o}}\left(C_{\mathrm{o}}-C_{\mathrm{s}}\right)$, and the intercept on the $y$ axis $\left(C_{\mathrm{s}}\right)$ estimates a value for the POC value of the resuspended particles. The estimated POC concentrations in the surface sediments $\left(C_{\mathrm{s}}\right)$ ranged from 1.3 to $1.8 \%$ (Table 2 ). The measured POC values in the surface sediments in the ECS in this study ranged from 0.20 to $0.54 \%$ (an average value $=0.34 \pm 0.14 \%$ ). Because the derived values of $C_{\mathrm{s}}$ in the CDW are much higher than published data (Table 2), herein the average $C_{\mathrm{s}}$ values (data from previous studies and this study; see Table 2) are used to represent the POC content of the surface sediments rather than using the derived $C_{\mathrm{s}}$ values. With the $C_{\mathrm{s}}$ data, we assume a reasonable surface phytoplankton weight $\left(S_{\mathrm{o}}=0.5 \mathrm{mg} \mathrm{L}^{-1}\right)$ to solve the $C_{\mathrm{o}}$ values. The statistical data of intercept and slope in different water masses (CDW, CUW and $\mathrm{KW}$ ) are shown in Table 3 . The predicted $C_{\mathrm{o}}$ (phytoplankton POC concentration) values in different water masses ranged from 9.9 to $28.3 \%$, which are in agreement with the published phytoplankton culture data (Thalassiosira weissflogii $(\mathrm{POC}=10.2-15.8 \%)$; Skeletonema sp. $(\mathrm{POC}=10.7-14.8 \%)$; Chaetoceros affinis (POC $=8.1-16.8 \%)$, Tseng, 2010). In comparison, both derived $C_{\mathrm{o}}$ and $C_{\mathrm{S}}$ in the ECS are comparable to previously data reported by Sheu et al. (1995), Kao et al. (2003) and Tseng (2010). The results demonstrate that our interpretation using 

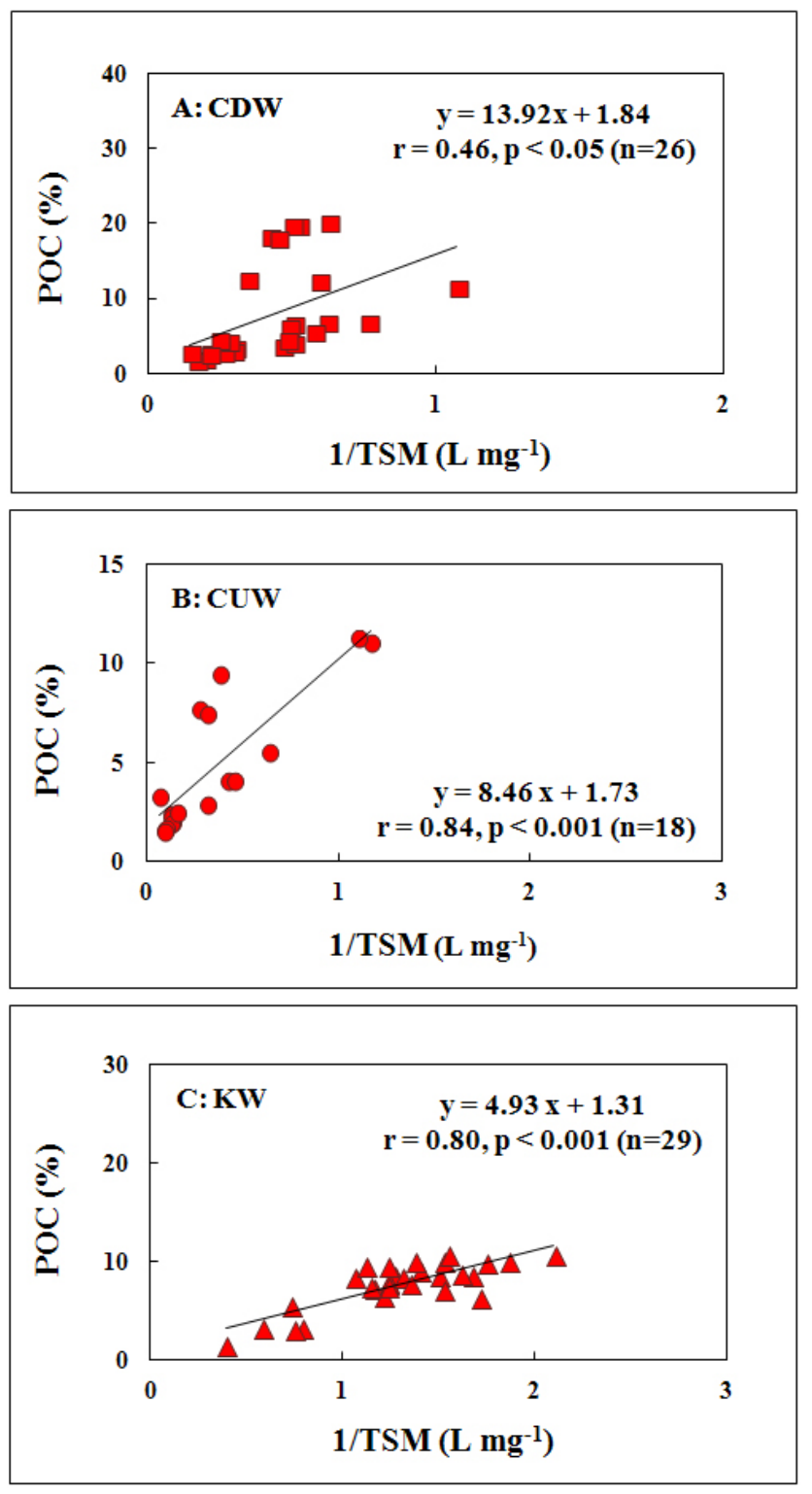

Fig. 5. (A) Relationships between POC (\%) and 1/TSM in the CDW of the ECS. (B) Relationship between POC (\%) and 1/TSM in the CUW of the ECS. (C) Relationship between POC (\%) and 1/TSM in the $\mathrm{KW}$ of the ECS.

a two end-member mixing model to describe particle mixing in the ECS seems to give reasonable results.

Secondly, with the two end-member values $\left(C_{\mathrm{s}}\right.$ and $\left.C_{\mathrm{o}}\right)$, we can use Eq. (2) (see below) reported by Bloesch (1994), to estimate the ratio of resuspended particles to total sinking particles in the ECS.

$R / T=\left(C_{\mathrm{t}}-C_{\mathrm{o}}\right) /\left(C_{\mathrm{s}}-C_{\mathrm{o}}\right)$,

where $R$ represents the fraction of resuspended particles (mg L ${ }^{-1}$, dry weight, $\mathrm{dw}$ ) collected by a sediment trap, $T$ the total entrapped sinking particles $\left(\mathrm{mg} \mathrm{L}^{-1}, \mathrm{dw}\right)$ collected
Table 2. Organic content $\left(C_{\mathrm{S}}, \%\right)$ in the surface sediments in the ECS.

\begin{tabular}{llcccc}
\hline $\begin{array}{l}\text { Water } \\
\text { mass }\end{array}$ & Station & $\begin{array}{l}C_{\mathrm{s}}{ }^{1} \\
(\%)\end{array}$ & $C_{\mathrm{s}}{ }^{2}$ & $C_{\mathrm{s}}{ }^{3}$ & $C_{\mathrm{s}}{ }^{4}$ \\
\hline CDW & S18 & 1.8 & 0.19 & 0.67 & $0.54 \pm 0.03$ \\
CDW & S19 & 1.8 & 0.66 & 0.19 & $0.42 \pm 0.20$ \\
SMW & S28 & 1.8 & 0.38 & 0.29 & $0.25 \pm 0.03$ \\
CDW & S29 & 1.8 & 0.27 & 0.28 & $0.22 \pm 0.02$ \\
CUW & S5 & 1.7 & 0.45 & 0.88 & $0.49 \pm 0.03$ \\
KW & S10 & 1.3 & 0.29 & 0.42 & $0.24 \pm 0.06$ \\
KW & S26 & 1.3 & 0.28 & 0.23 & $0.20 \pm 0.09$ \\
\hline
\end{tabular}

\footnotetext{
1 Model-estimated values,

2 Sheu et al. (1995),

3 Kao et al. (2003).

4 This study (average \pm 1 std, $n=4$ ).
}

by a sediment trap, and $C_{\mathrm{t}}$ the organic fraction of observed sinking particles (\%). With $C_{\mathrm{t}}, C_{\mathrm{o}}$, and $C_{\mathrm{s}}$, the ratio $(R / T)$ of resuspended particles to entrapped sinking particles can be estimated from Eq. (2). Consequently, the corrected POC flux can be calculated based on Eq. (3).

Corrected (Corr.) POC flux $=$ uncorrected POC flux $\times(1-R / T)(3)$

The detailed data of $R / T$, uncorrected and corrected POC fluxes are summarized in Table 4 . The predicted $R / T$ in trapped particles of the ECS ranged from approximately $27 \%$ to $93 \%$ with higher values in the inner shelf and lower values in the outer shelf, suggesting that sediment resuspension is a ubiquitous phenomenon in the ECS. If resuspension results in the outer shelf $(27-58 \%)$ of the ECS in this study are excluded, the resuspension results (57-93\%) in this study seem to be similar to the estimated resuspension ratios (70-94\%) in the inner and middle shelves of the Yellow Sea and the ECS (Guo et al., 2010). The corrected POC fluxes $\left(58 \pm 33-63 \pm 36 \mathrm{mg} \mathrm{C} \mathrm{m}^{-2} \mathrm{~d}^{-1}\right)$ in the outer and middle shelves gradually increased to $297 \pm 168$ $785 \pm 438 \mathrm{mg} \mathrm{C} \mathrm{m}^{-2} \mathrm{~d}^{-1}$, which are all lower than the PP values (Table 5) in the ECS, revealing that appropriate corrections for constraining POC fluxes in marginal seas are necessary.

\section{Discussion}

\subsection{Spatial POC variation, $O C$ content in sediments and possible POC flux impact in the ECS}

The good correlations between POC and Chl $a$ (or TSM) are found in most regions of the ECS, but there are some data (i.e., the data in the blue circles in Fig. 4a, b and d) away from the correlations. It is reasonable to predict that in situ phytoplankton species composition and abundance are mainly responsible for production of POC, and thus result in good correlations among these parameters in the ECS. For example, Chang et al. (2003) reported strong spatial variation of 
Table 3. Statistical data of linear regressions of POC values versus the reciprocal of total suspended matter concentrations in the East China Sea. The unit of $C_{\mathrm{S}}$ and $C_{\mathrm{o}}$ is $\% . C_{\mathrm{o}}(\max )$ and $C_{\mathrm{o}}(\mathrm{min})$ represent the minimum and maximum derived POC concentrations of phytoplankton.

\begin{tabular}{lcccccc}
\hline $\begin{array}{l}\text { Water } \\
\text { mass }\end{array}$ & Station & $\begin{array}{c}\text { Slope } \\
S_{\mathrm{o}}\left(C_{\mathrm{o}}-C_{\mathrm{S}}\right)\end{array}$ & $\left(C_{\mathrm{S}}\right)$ & $\begin{array}{c}C_{\mathrm{o}} \\
\left(S_{\mathrm{o}}=0.5\right)\end{array}$ & $\begin{array}{c}C_{\mathrm{o}}(\max ) \\
\left(S_{\mathrm{o}}=0.25\right)\end{array}$ & $\begin{array}{c}C_{\mathrm{o}}(\min ) \\
\left(S_{\mathrm{o}}=0.75\right)\end{array}$ \\
\hline CDW & S18 & 13.9 & 0.54 & 28.3 & 56.1 & 19.1 \\
CDW & S19 & 13.9 & 0.42 & 27.9 & 55.7 & 18.7 \\
SMW & S28 & 13.9 & 0.25 & 28.0 & 55.8 & 18.8 \\
CDW & S29 & 13.9 & 0.22 & 28.0 & 55.8 & 18.7 \\
CUW & S5 & 8.5 & 0.49 & 13.3 & 26.1 & 9.0 \\
KW & S10 & 4.9 & 0.24 & 10.0 & 19.8 & 6.7 \\
KW & S26 & 4.9 & 0.20 & 9.9 & 19.7 & 6.6 \\
\hline
\end{tabular}

$S_{\mathrm{O}}$ is the total weight of surface phytoplankton $\left(\mathrm{mg} \mathrm{L}^{-1}\right)$.

$C_{\mathrm{O}}$ is the POC concentration of phytoplankton (\%).

$C_{\mathrm{S}}$ is the OC concentration of surface sediment $(\%)$.

Table 4. Detailed values of $C_{\mathrm{t}}, R / T$, uncorrected POC flux (Uncorr. POC flux) and corrected POC flux (Corr. POC flux \pm uncertainty) in the different areas of the ECS.

\begin{tabular}{llcccc}
\hline $\begin{array}{l}\text { Water } \\
\text { mass }\end{array}$ & Station & $\begin{array}{c}C_{t} \\
(\%)\end{array}$ & $\begin{array}{c}R / T \\
(\%)\end{array}$ & $\begin{array}{c}\text { Uncorr. POC flux } \\
\left(\mathrm{mg} \mathrm{C} \mathrm{m}^{-2} \mathrm{~d}^{-1}\right)\end{array}$ & $\begin{array}{c}\text { Corr. POC flux } \\
\left(\mathrm{m} \mathrm{C} \mathrm{m}^{-2} \mathrm{~d}^{-1}\right)\end{array}$ \\
\hline CDW & S18 & 6.1 & 80 & 3900 & $785 \pm 438$ \\
CDW & S19 & 2.0 & 93 & 7300 & $486 \pm 275$ \\
SMW & S28 & 9.9 & 65 & 200 & $69 \pm 39$ \\
CDW & S29 & 11.2 & 60 & 750 & $297 \pm 168$ \\
CUW & S5 & 5.9 & 57 & 720 & $307 \pm 169$ \\
KW & S10 & 7.3 & 27 & 80 & $58 \pm 33$ \\
KW & S26 & 4.2 & 58 & 150 & $63 \pm 36$ \\
\hline
\end{tabular}

$R$ represents the fraction of resuspended particles $\left(\mathrm{mg} \mathrm{L}^{-1}\right.$, dry weight, dw) collected by a sediment trap.

$T$ : total entrapped sinking particles $\left(\mathrm{mg} \mathrm{L}^{-1}, \mathrm{dw}\right)$ collected by a sediment trap.

$C_{\mathrm{t}}$ : organic fraction of observed sinking particles (\%).

Note: the uncertainty of the calculated fluxes was based on the standard deviation of three $C_{\mathrm{o}}$ values $\left(C_{\mathrm{o}}, C_{\mathrm{o}}(\min ), C_{\mathrm{o}}(\max )\right)$.

carbon: Chl $a$ values in the ECS with low values in the inner shelf and high values in the middle (or outer) shelves using the POC-Chl $a$ regression (inner POC/Chl $a$ : middle POC / Chl $a=13: 93 \mathrm{~g} \mathrm{~g}^{-1}$ ) and phytoplankton cell volume (inner POC/Chl $a$ : middle POC / Chl $a=18: 67 \mathrm{~g} \mathrm{~g}^{-1}$ ). Chang et al. (2003) also suggested that carbon: Chl $a$ variations are due to phytoplankton species difference and phytoplankton cell abundance. For example, Skeletonema costatum and Synechococcus spp., Synechococcus spp. and Pseudosolenia calcar-avis, and Trichodesmium spp and nanoflagellates are the main phytoplankton groups contributing autotrophic carbon in the inner ( $75 \%$ of autotrophic carbon), middle (79\% of autotrophic carbon) and outer ( $80 \%$ of autotrophic carbon) shelves, respectively. Therefore, the insiders in the dotted circles in Fig. 4a, b and d could be the results of different phytoplankton species composition and cell abundance.

Vertical profiles of POC were reflected in elevated Chl $a$ patterns in the inner shelf and outer shelf, while at stations 29 and 26, POC concentrations at the lower depths were higher than at shallow depths, implying lateral transport or sediment resuspension at greater depth. Similarly, vertical profiles of TSM showed similar patterns as POC profiles (Fig. 3e and f). One can easily see that TSM concentrations at lower depths at all stations were higher than at more shallow depths, suggesting that sediment resuspension and/or lateral transport of TSM are remarkable features in the ECS. Iseki et al. (2003) also suggested that the bottom turbid layer (BTL) is a potential source of downslope transport of resuspended particles on the shelf.

Particle resuspension is known in the shelf to play a major role in transporting carbon, but in the vicinity of large rivers, plumes containing fluvial particles can also influence POC fluxes. However, it is difficult to evaluate the contribution of fluvial POC from the Changjiang River without suitable tracers such as rare earth elements in both suspended and sinking particles (Hsu et al., 2010). Alternatively, we can estimate the contribution of phytoplankton carbon to total carbon in the inner shelf using previously reported autotrophic carbon based on cell volume 
measurements (Chang et al., 2003). The phytoplankton carbon level in the inner shelf was $143 \mathrm{mg} \mathrm{C} \mathrm{m}^{-3}$ and accounted for $47.7 \%$ of POC concentration $\left(\sim 300 \mathrm{mg} \mathrm{C} \mathrm{m}^{-3}\right.$; the detailed information can be found in Chang et al., 2003). Nevertheless, other factors, such as dead phytoplankton cells, zooplankton, resuspended particles, and fecal pellets are likely sources of POC in the water column. The result suggests that the Changjiang plume carrying fluvial particles in the water column of the inner shelf approximately contributes $<50 \%$ to measured POC concentration. Moreover, distributions of salinity, sigma- $T\left(\mathrm{~kg} \mathrm{~m}^{-3}\right)$ and $\mathrm{NO}_{3}$ in the inner shelf (station 19, 19A and 29) are shown in Fig. 6a suggesting that low PP in the inner shelf with riverine influence could be caused by high turbidity and water stratification rather than nutrient limitation. As a consequence, it will cause a higher $e$ ratio due to low PP values. Furthermore, beside low PP in the inner shelf, one may see the lowest PP appearing in the inner shelf (i.e., S5) too. It could be mainly caused by nutrient limitation (Fig. 6b) and high total suspended matter (TSM $>1-2 \mathrm{mg} \mathrm{L}^{-1}$, e.g., a light effect). The low concentrations of nitrate at station 5 support the phenomenon reflecting that the higher POC was a passive result while the low PP is an in situ measured parameter when incubated in the bottles. As shown in Fig. 6b, the nitrate concentration in the water column at station 5 was almost close to zero, which will significantly inhibit phytoplankton growth, and then result in low $\mathrm{PP}$ value. Therefore, the $e$ ratio (POC flux/PP) will be increased because of low PP.

As mentioned above, POC sources are mainly from in situ phytoplankton (also zooplankton) production, detritus, terrestrial input, and fluvial carbon. Recently, a hypoxia zone (dissolved oxygen concentration $<62.5 \mu \mathrm{M}$ ) has been noticed in the estuarine and coastal regions of the ECS (Chen et al., 2007, 2013; Wang, 2009; Zhu et al., 2011), but the mechanisms for the occurrence of oxygen depletion is still unclear. Our data support the contention that high organic matter fluxes may consume oxygen in the near-bottom waters off the Changjiang diluted water regions during the summer, as was reported by Chen et al. (2007) and Zhu et al. (2011).

Most organic carbon (OC) concentrations in surface sediments in this study are slightly lower than previous data (Table 2, Sheu et al., 1995; Kao et al., 2003). In comparison, OC contents in surface sediments of the ECS ranged from 0.1 to $0.4 \%$ for the majority of the ECS continental shelf sediments (Lin et al., 2002). Other scientists reported that OC contents in the ECS ranged from 0.1 to $0.9 \%$ (Sheu et al., 1995; Kao et al., 2003). It is difficult to find the real reasons to interpret the difference among these studies. Lin et al. (2002) pointed out that OC contents less than (or close to) $0.2 \%$ were found in the outer shelf area where approximately $90 \%$ of the sediments were composed of coarse-grained quartz and/or carbonate sand. Low concentrations of $\mathrm{OC}$ found in the middle shelf and were possibly a combined result of limited finegrained and large sediments (Lin et al., 2000). It is worth noting that the model-derived high values of surface organic car-
(A)
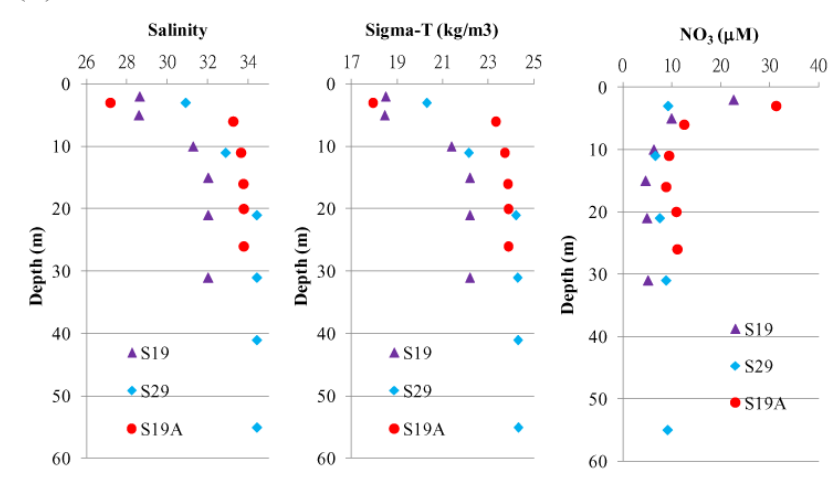

(B)

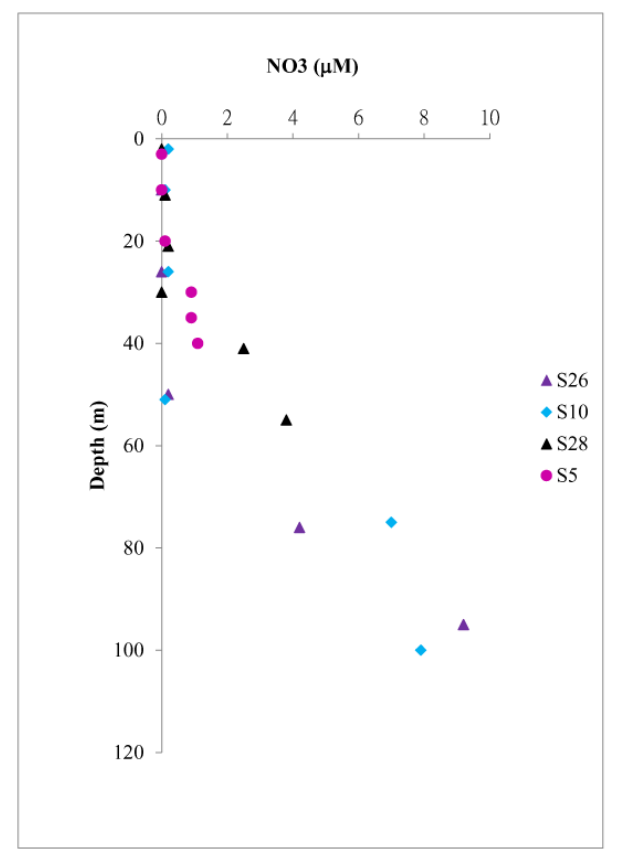

Fig. 6. (A) Distributions of salinity, sigma- $T$ and nitrate in the inner shelf stations S19, S19A and S29. (B) Distributions of vertical nitrate (S26, S28, S10 and S5) in the East China Sea.

bon could be caused by extrapolation of the mixing model or selective mobilization of lightest fraction (i.e., organic matter rich material) of the bed sediment during resuspension (Jago and Jones, 1998; Jones et al., 1998; Bale and Morris et al., 1998). In addition, the OC values (Table 2) in this study were the average value of bed sediments within $2 \mathrm{~cm}$ rather than only surface sediment (i.e., with elevated organic carbon sediment).

\subsection{Sensitivity of the vertical particle mixing model and comparison of the resuspension of trapped matter in different regions}

Two parameters, $C_{\mathrm{s}}$ and $C_{\mathrm{o}}$, will affect the ratio of resuspended particles to total sinking particles in Eq. (2). If we use 
Table 5. Data of corrected POC flux (POC flux), primary production (PP) and $e$ ratio (POC flux / PP) in the ECS.

\begin{tabular}{llcccccc}
\hline $\begin{array}{l}\text { Water } \\
\text { mass }\end{array}$ & Station & $\begin{array}{c}\text { Bottom depth } \\
(\mathrm{m})\end{array}$ & $\begin{array}{c}\text { EZ } \\
(\mathrm{m})\end{array}$ & $\begin{array}{c}\text { Trap depth } \\
(\mathrm{m})\end{array}$ & $\begin{array}{c}\text { POC flux } \\
\left(\mathrm{m} \mathrm{C} \mathrm{m}^{-2} \mathrm{~d}^{-1}\right)\end{array}$ & $\begin{array}{c}\text { PP } \\
\left(\mathrm{m} \mathrm{C} \mathrm{m}^{-2} \mathrm{~d}^{-1}\right)\end{array}$ & $e$ ratio \\
\hline CDW & S18 & 47 & 15 & 20 & $785 \pm 438$ & 1897 & $0.41 \pm 0.23$ \\
CDW & S19 & 38 & 22 & 20 & $486 \pm 275$ & 3045 & $0.16 \pm 0.09$ \\
SMW & S28 & 60 & 50 & 30 & $69 \pm 39$ & 600 & $0.12 \pm 0.07$ \\
CDW & S29 & 57 & 26 & 20 & $297 \pm 168$ & 3377 & $0.09 \pm 0.05$ \\
CUW & S5 & 51 & 36 & 20 & $307 \pm 169$ & 337 & $0.91 \pm 0.50$ \\
KW & S10 & 154 & 90 & 120 & $58 \pm 33$ & 1153 & $0.05 \pm 0.03$ \\
KW & S26 & 118 & 74 & 100 & $63 \pm 36$ & 442 & $0.14 \pm 0.08$ \\
\hline
\end{tabular}

the predicted $C_{\mathrm{s}}\left(C_{\mathrm{s}}^{1}\right.$ in Table 2$)$ and a fixed $C_{\mathrm{t}}$ and $C_{\mathrm{o}}$, to estimate the $R / T$, the variation of $R / T$ in the study area ranges from $4 \%$ to $9 \%$, suggesting that $R / T$ is not significantly affected by $C_{\mathrm{s}}$ (detailed data shown in the Supplement). However, most derived $C_{\mathrm{s}}$ values are higher than the observed OC values in the surface sediments of the ECS, suggesting that discharge of suspended particles (with low carbon high TSM) of the Changjiang River could affect the results besides bottom sediment resuspension (Zhu et al., 2006; Guo et al., 2010). These results illustrate that the derived $C_{\mathrm{s}}$ values need appropriate adjustment by field-observed OC data in the sediments.

If we use a given $C_{\mathrm{o}}\left(\mathrm{S}_{\mathrm{o}}=0.25 \mathrm{mg} \mathrm{L}^{-1}\right.$, about $50 \%$ of uncertainty) and a fixed $C_{\mathrm{t}}$ and $C_{\mathrm{s}}$ to estimate the $R / T$, the variation of $R / T$ ranges from $3 \%$ to $51 \%$ (on average $28 \%$ ) (detailed data shown in the Supplement). If we change $C_{\mathrm{o}}$ to $\left(S_{\mathrm{o}}=0.75\right)$ and fix $C_{\mathrm{t}}$ and $C_{\mathrm{s}}$, the variation of $R / T$ ranges from $4 \%$ to $51 \%$ (on average $29 \%$ ). The results suggest that $C_{\mathrm{o}}$ is more sensitive than $C_{\mathrm{s}}$. If we use $S_{\mathrm{O}}=0.5 \mathrm{mg} \mathrm{L}^{-1}$ to estimate $R / T$, then the predicted $C_{\mathrm{o}}$ will be 13.4 to $21.9 \%$, which is very close to the phytoplankton culture data (10-17\%, Tseng, 2010). Overall, the vertical mixing model is a simple approach to constrain the effect of resuspended particles on POC flux effectively, but it is not a perfect tool in the inner shelf in the turbid waters under fluvial influence, because resuspended particles cannot be completely separated from sinking particles.

As shown in Table 5, the corrected POC fluxes in this study in the inner and middle shelves are much lower than POC flux values reported by Iseki et al. (2003). Firstly, as we mentioned, the mixing model cannot distinguish fluvial suspended matter from resuspended sediments. Secondly, Iseki et al. (2003) found elevated POC fluxes always occurring within the bottom turbid layer, which might have significant particle resuspension, but they did not calibrate it. Thirdly, the deployment depths of sediment traps and hydrographic settings between two studies are different so that it is difficult to compare them.

In coastal areas, continental shelves or marginal seas, sediment resuspension phenomenon is ubiquitous (Lampitt, 1985; Jones et al., 1998; Bales and Morris, 1998; Bonnin et al., 2002; Guo et al., 2010), but estimated resuspension by model or two end-member approaches is limited. To date, only a few investigations have reported the sediment resuspension impact on trapped matter or organic carbon in lakes, shelf regions and deep water (Table 6, Rosa, 1985, Bonnin et al., 2002; Heussner et al., 2006; Guo et al., 2010). For instance, resuspension (or called rebound sediments) matter trapped by sediment traps in shallow water $(<100 \mathrm{~m})$ region in Lake Ontario, Yellow Sea or ECS ranged from 63 to $94 \%$ for trapped organic carbon and was approximately $85 \%$ for trapped matter (Table 6). In deep water, resuspension in Faroe-Shetland Channel or Gulf of Lions ranged from 32 to $70 \%$ for trapped matter (Table 6). In comparison, the estimated results of resuspension in this study are in agreement with previously reported results although survey regions are different.

\subsection{Possible carbon export in the ECS}

POC fluxes in the ECS have been constrained by the vertical mixing model, while it is difficult to distinguish the effect of POC flux from Changiiang influence with turbid waters. As discussed above, suspended particle discharge from the Changjiang River may affect the POC flux calculation in the inner shelf. Herein we only attempt to estimate POC export in the outer shelf (i.e., stations 10 and 26). The POC buried in the sediment of stations 10 and 26 (i.e., the outer shelf) is approximately 9 and $5 \mathrm{mg} \mathrm{C} \mathrm{m}^{-2} \mathrm{~d}^{-1}$, respectively (Tseng, 2010). The remineralization carbon in the outer shelf is approximately $6 \mathrm{mg} \mathrm{C} \mathrm{m}^{-2} \mathrm{~d}^{-1}$, according to organic phosphorus mineralization to carbon ratio (Fang et al., 2007). As a result, the lateral POC exports at stations 10 and 26 (i.e., the outer shelf of the ECS) are roughly 43 and $52 \mathrm{mg} \mathrm{C} \mathrm{m}^{-2} \mathrm{~d}^{-1}$, respectively. The lateral carbon export rate (i.e., $e$ ratio $=\mathrm{POC}$ flux $/ \mathrm{PP}=0.05 \pm 0.03-0.14 \pm 0.08$, Table 5) in the outer shelf is similar to that in the oligotrophic ocean, when compared to other investigations (Hung and Gong, 2007, $e$ ratio $=0.05-0.11$ in the oligotrophic Kuroshio water; Guo et al., 2010, $e$ ratio $=0.18$ in the middle shelf of the ECS; Hung et al., 2010c, $e$ ratio $=0.11-0.16$ in the middle shelf of the southern ECS). Particles can be carried out of the ECS in the bottom turbid layer to remote regions 
Table 6. Estimated resuspension of total trapped mater or organic carbon collected by sediment traps in different regions.

\begin{tabular}{lccl}
\hline Location & $\begin{array}{c}\text { Bottom depth } \\
(\mathrm{m})\end{array}$ & $\begin{array}{c}\text { Resuspension } \\
(\%, \mathrm{TM} \text { or OC) }\end{array}$ & Reference \\
\hline Lake Ontario (inshore) & 23 & $85(\mathrm{TM}), 63(\mathrm{OC})$ & Rosa $(1985)$ \\
Lake Ontario (offshore) & 130 & $33(\mathrm{TM}), 9(\mathrm{OC})$ & Rosa (1985) \\
Faroe-Shetland Channel & $700-800$ & $70(\mathrm{TM})$ & Bonnin et al. (2002) \\
\hline Gulf of Lions (Planier) & $500 \& 1000^{*}$ & $32-41(\mathrm{TM})$ & Heussner et al. (2006) \\
Gulf of Lions (Lacaze) & $500 \& 1000^{*}$ & $60-67(\mathrm{TM})$ & Heussner et al. (2006) \\
Yellow Sea & 73 & $94(\mathrm{OC})$ & Guo et al. (2010) \\
East China Sea & $55-88$ & $70-89(\mathrm{OC})$ & Guo et al. (2010) \\
East China Sea & $38-60$ & $57-93(\mathrm{OC})$ & This study \\
East China Sea & $118-154$ & $27-58(\mathrm{OC})$ & This study \\
\hline
\end{tabular}

* trap depth. TM: total trapped matter; OC: trapped organic carbon.

(Hoshika et al., 2003) and/or enter the open ocean interior or partly deposited near northern Okinawa Trough (Fig. 1).

Besides the carbon export in the outer shelf of the ECS, we also find a higher carbon export rate $(e$ ratio $=0.09-0.41$ for CDW and $91 \%$ for CUW) in the CDW and CUW regions. The higher carbon export rate in the CDW regions is mainly caused by strong phytoplankton primary production because of high nutrient supply from the Changjiang River and/or partly from the Changjiang plume carrying fluvial particles. The high $e$ ratios in this study are similar to the reported values in the middle Yellow Sea and in the upwelling region off Zhejiang by Guo et al. (2010). While the nutrient supply in the CUW is not pronounced, the question arises as to why the carbon export rate is so high. Possible explanations are the following: (1) PP is limited by light intensity (due to high suspended particles, TSM $>1-2 \mathrm{mg} \mathrm{L}^{-1}$ ), (2) nutrient limitation in the surface layer or (3) strong vertical mixing (e.g., water un-stabilization). Regardless of the POC flux values in the inner shelf, there is another unanswered question: where is the carbon going? This study indeed provides quantitative POC flux data, but it is difficult to compare them with direct evidence. Another possible transport pathway in the inner shelf would be south, along the coast, with eventual burial in the southern Okinawa Trough (Liu et al., 2000). According to Berelson (2002), the average settling velocity of particles in the ocean ranges from 100 to $300 \mathrm{~m} \mathrm{~d}^{-1}$. Given that the water depth in the ECS ranges from 30 to $200 \mathrm{~m}$, particles would settle in a day or less. In other words, particles are being transported, undergo continuous sinking and resuspension in the bottom turbid layer (Hoshika et al., 2003) or to the bottom of sediments. Tsai (1996) also reported that when tidal currents flow eastward in the southern ECS, the suspended particulate matter flux is elevated, revealing that tidal currents are an important mechanism for transporting particles from marginal seas to the open ocean. Therefore, we suggest that lateral POC transport is driven by the interactions of surface sediment resuspension with tidal currents, or contour currents or via isopycnal diffusion. Apparently, fine particles did not accumulate in the middle shelf (Kao et al.,
2003), suggesting that these fine particles were transported elsewhere.

\subsection{Rare earth element}

Some rare earth elements (REEs) such as light rate earth elements (LREES) have been used as proxies to evaluate sediment sources in numerous settings (Goldstein and Jacobsen, 1988; Zhang et al., 1998; Sholkovitz et al., 1999; Li et al., 2013). Most LREES (Table 7) in this study have difficulties in distinguishing suspended particles from sediments based on their levels, but Eu concentrations in particles seem to be a good tracer due to remarkable differences between suspended particles and sediments. Therefore, we used the Eu anomaly $\left(\mathrm{Eu} / \mathrm{Eu}^{*}\right)\left(\mathrm{Eu}^{*}=1.90 \pm 0.07 \mu \mathrm{g} \mathrm{g}^{-1}\right.$ was the average value of $\mathrm{Eu}^{*}$ in both sediment $\left(1.85 \mu \mathrm{g} \mathrm{g}^{-1}\right)$ and suspended particles $\left(1.95 \mu \mathrm{g} \mathrm{g}^{-1}\right)$, which was referred to from the reported values of Zhang et al. (1998), who obtained a linear interpolation between $\mathrm{Sm}$ and $\mathrm{Tb}$ on the chondritenormalized curve) to identify possible end-members (suspended particles and sediments) that contribute to sinking particles in this study. For example, the $\mathrm{Eu} / \mathrm{Eu}^{*}$ anomalies on the sediment and suspended particles off the Yangtze River (Changjiang) mouth (near station 19) were 0.48 and 0.67 (Fig. 7), respectively. The value of $\mathrm{Eu} / \mathrm{Eu}^{*}$ in the sinking particles at station 19 was 0.62 . If a two-end-member mixing model is used to estimate the contribution of suspended and sediment on sinking particles, the fractions of suspended particles and sediment will account for $74 \%$ and $26 \%$ of sinking particles, respectively. The result suggests that $R / T(0.26)$ is significantly lower than the estimated value $(R / T=0.93)$ by using TSM-OC mixing model. This approach may not truly reflect resuspension value in this study because the Eu anomaly value should be from this study rather than from an estimated value from $10 \mathrm{yr}$ ago (Zhang et al., 1998). Moreover, particularly in shallow areas the dynamics of sediment settling and resuspension can be highly dependent on the seasonal and interannual changes of Changjiang discharge, which may affect the Eu anomaly 
Table 7. Concentrations of light rare earth elements (LREEs) in the sinking particles, sediment and suspended matter (SPM) in the East China Sea.

\begin{tabular}{lccccccc}
\hline Station & $\begin{array}{c}\mathrm{La} \\
\left(\mu \mathrm{g}^{-1}\right)\end{array}$ & $\begin{array}{c}\mathrm{Ce} \\
\left(\mu \mathrm{g} \mathrm{g}^{-1}\right)\end{array}$ & $\begin{array}{c}\mathrm{Pr} \\
\left(\mu \mathrm{gg}^{-1}\right)\end{array}$ & $\begin{array}{c}\mathrm{Nd} \\
\left(\mu \mathrm{gg}^{-1}\right)\end{array}$ & $\begin{array}{c}\mathrm{Sm} \\
\left(\mu \mathrm{g} \mathrm{g}^{-1}\right)\end{array}$ & $\begin{array}{c}\mathrm{Eu} \\
\left(\mu \mathrm{g} \mathrm{g}^{-1}\right)\end{array}$ & $\begin{array}{c}\mathrm{Gd} \\
\left(\mu \mathrm{g} \mathrm{g}^{-1}\right)\end{array}$ \\
\hline S18 & 40.87 & 72.44 & 6.77 & 35.18 & 5.37 & 1.11 & 5.61 \\
S19 & 44.29 & 78.94 & 7.86 & 40.40 & 6.25 & 1.23 & 6.18 \\
S28 & 4.17 & 4.86 & 0.24 & 0.46 & $\mathrm{ND}$ & $\mathrm{ND}$ & $\mathrm{ND}$ \\
S29 & 17.92 & 31.27 & 2.85 & 14.44 & 1.63 & 0.44 & 1.47 \\
S5 & 42.80 & 78.76 & 7.15 & 37.01 & 5.09 & 1.06 & 5.21 \\
S10 & 11.04 & 21.99 & 1.84 & 9.84 & 1.20 & 0.31 & 0.98 \\
S26 & 23.88 & 43.20 & 4.19 & 21.64 & 3.27 & 0.65 & 3.22 \\
Sediment* & 43.00 & 86.00 & $\mathrm{ND}$ & 44.00 & 6.00 & 0.89 & $\mathrm{ND}$ \\
SPM $^{*}$ & 44.00 & 85.00 & $\mathrm{ND}$ & 40.00 & 6.00 & 1.31 & $\mathrm{ND}$ \\
\hline
\end{tabular}

* The data of sediment and SPM were from the river mouth (near station 19) of Yangtze River in Zhang et al. (1998). ND: no data.

value. Furthermore, we should provide Eu values in both suspended particles and sediments, while the rare earth elements in this study were not available due to the fact that we used GF/F filters. The fractions of REE are a potential approach to evaluate the possible contribution of suspended and resuspended particles in marginal seas where a large river empties into it. The estimated percentage of resuspended particles based on REE is different from the mixed model on organic matter, but it may reflect the fact that each component of REE shows a distinctive nature during weathering, erosion, and fluvial transportation (McLennan, 1989). As mentioned before, the resuspension particles were likely from lightest organic matter, which can be different from REE characteristics, but REE data can provide another avenue to know if suspension exists in the study area.

\subsection{Comparing short-time measurements of POC fluxes and PP values with long-time estimates of ${ }^{234} \mathrm{Th}$ - derived POC fluxes and satellite-derived PP}

In this study, one may ask questions if short-time (hours-day) measurements of sediment-trap-measured POC fluxes and C14 incubation PP values are reliable. First, sediment traps are often used to measure POC flux directly, despite possible biases by hydrodynamic and biological effects (Gardner, 1980; Gardner et al., 1983; Lee et al., 1988; Karl and Knauer, 1989). Furthermore, Marty et al. (2009) reported that shortterm fluctuations of POC fluxes were quite obvious with a diel periodicity: higher POC fluxes during the night period and lower POC fluxes during the day period. However, $\mathrm{Li}$ (2009) investigated POC fluxes using a time series $(4,8$, 12 and $24 \mathrm{~h}$ ) of trap deployments in the ECS and found no significant difference in POC flux between night and day. Hung et al. (2010c) also reported that daytime POC fluxes (8 a.m. to 5 p.m.) at $120 \mathrm{~m}$ and $150 \mathrm{~m}$ in the outer shelf of the ECS off northeastern Taiwan in summer in 2008 were $46 \pm 7 \mathrm{mg} \mathrm{C} \mathrm{m}^{-2} \mathrm{~d}^{-1}$ and $48 \pm 8 \mathrm{mg} \mathrm{C} \mathrm{m}^{-2} \mathrm{~d}^{-1}$, respectively. Nighttime POC fluxes (12 a.m. to 9 a.m.) at $120 \mathrm{~m}$ and
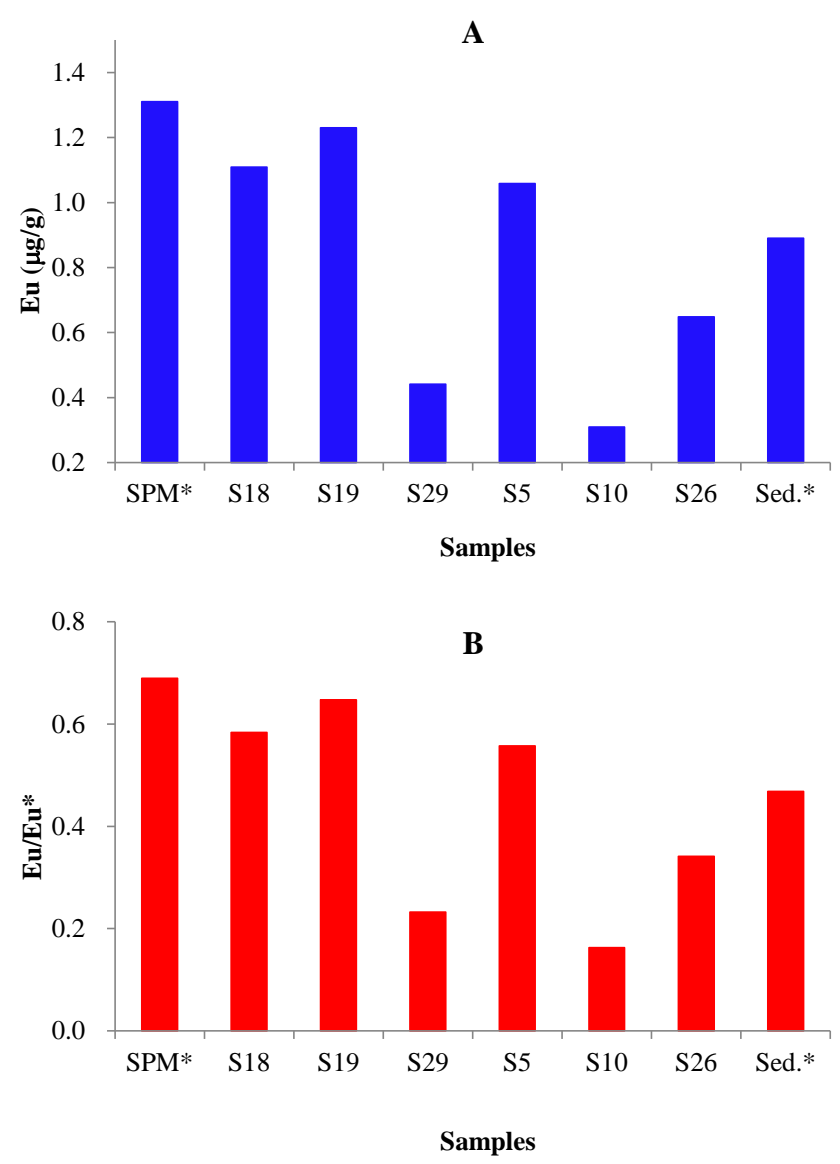

Fig. 7. (A) Distribution of rare earth elements in the sinking particles of the ECS. (B) Normalized Eu distribution in the sinking particles of the ECS. The Eu* $\left(1.90 \pm 0.07 \mu \mathrm{g} \mathrm{g}^{-1}\right)$ in Fig. 7 was the average value of $\mathrm{Eu}^{*}$ in both sediment $\left(1.85 \mu \mathrm{g} \mathrm{g}^{-1}\right)$ and suspended particle $\left(1.95 \mu \mathrm{g} \mathrm{g}^{-1}\right)$, which was referred to from the Table 4 of Zhang et al. (1998), who obtained a linear interpolation between $\mathrm{Sm}$ and $\mathrm{Tb}$ on the chondrite-normalized curve. 
$150 \mathrm{~m}$ were $53 \pm 9 \mathrm{mg} \mathrm{C} \mathrm{m}^{-2} \mathrm{~d}^{-1}$ and $44 \pm 7 \mathrm{mg} \mathrm{C} \mathrm{m}^{-2} \mathrm{~d}^{-1}$, respectively, suggesting no variation in the fluxes occurred between night and day. The inconsistent field observations may reflect the fact that POC fluxes are affected by both physical and biological processes simultaneously. Moreover, content of sinking particles also contains other detritus, dead phytoplankton cells, aggregates, etc. besides fecal pellets. Our floating trap is designed to collect passive vertical particles below or close to the depth of the euphotic zone so that we cannot catch active particles such as deep fecal pellets, which is a difficult part to estimate in terms of its mass and POC content. More studies are needed for this in the future. Furthermore, the trapping efficiency of sediment traps is variable and it may also give additional uncertainties to our estimate of the POC fluxes in the ECS.

Besides sediment traps, ${ }^{234} \mathrm{Th}$ has been increasingly used as a tracer to estimate POC flux due to its timescales (weeks to month) in surface water (Coale and Bruland, 1985; Santschi et al., 2006) based on calculation of the product of the POC / ${ }^{234} \mathrm{Th}$ ratio in sinking particles and the ${ }^{234} \mathrm{Th}$ flux. Although both methods have their uncertainties (see review in Buesseler et al., 2006, 2007; Hung and Gong, 2010; Xu et al., 2011; Hung et al., 2012), recent studies have shown that both methods are complementary means for estimating POC flux in the upper ocean in different marine environments including the ECS, the Kuroshio, the South China Sea, the Gulf of Mexico, and the oligotrophic northwestern Pacific Ocean (Hung and Gong, 2007; Li, 2009; Hung et al., 2004, 2010c; Wei et al., 2011). The POC fluxes measured by sediment traps and ${ }^{234} \mathrm{Th}$ approaches in the Kuroshio, the Gulf of Mexico, and the South China Sea are in good agreement if the ratio of $\mathrm{POC} /{ }^{234} \mathrm{Th}$ is appropriately selected. These results support that our short-time sediment trap method is reliable.

Secondly, short-time (hours incubation) PP experiment was conducted in the ECS covering all four seasons by Gong et al. (2003), and the results showed seasonal variations with elevated values in the inner shelf of the ECS and low values in the outer shelf of the ECS. For example, PP values in the southern ECS off northeastern Taiwan were approximately $400-500 \mathrm{mg} \mathrm{C} \mathrm{m}^{-2} \mathrm{~d}^{-1}$ in summer under good weather conditions. In comparison, Siswanto et al. (2009) reported that the satellite-derived PP value (daily data) in the southern ECS in summer in 2005 under non-typhoon conditions was approximately $500 \mathrm{mg} \mathrm{C} \mathrm{m}^{-2} \mathrm{~d}^{-1}$, which is in good agreement with the PP values. Recently, Hung et al. (2010c) reported that PP values estimated by the model (1283 $\mathrm{m} \mathrm{C} \mathrm{m}^{-2} \mathrm{~d}^{-1}$, Behrenfeld and Falkowski, 1997) and by C-14 incubation $\left(1773 \mathrm{mg} \mathrm{C} \mathrm{m}^{-2} \mathrm{~d}^{-1}\right.$, Gong et al., 2003; $1367-1945 \mathrm{mg} \mathrm{C} \mathrm{m}^{-2} \mathrm{~d}^{-1}$, Shih et al., 2013) in the southern ECS after typhoon events in 2007 and 2008 are quite comparable if the analytical uncertainty $(20-30 \%)$ is considered. The enhanced PP after a typhoon event was mainly caused by high nutrient supply via both vertical mixing and upwelling. The detailed discussion can be found in Hung et al. (2010c). In other words, data (POC fluxes and PP values) obtained from short-term measurements by sediment traps and C-14 incubation are comparable to long-term methods such as ${ }^{234} \mathrm{Th}$-derived approaches and satellite-derived PP values.

\section{Conclusions}

This study involved direct measurement of POC fluxes and primary production in the ECS. It was found that some of POC fluxes were higher than primary production, suggesting that the lower PP might be inhibited due to water stratification and light limitation in the inner shelf. A vertical particle mixing model was used to correct effects of bottom sediment resuspension. The corrected POC fluxes in the inner, middle and outer shelves thus obtained were $297 \pm 168-785 \pm 438$, $69 \pm 39$ and $58 \pm 33 \mathrm{mg} \mathrm{C} \mathrm{m}^{-2} \mathrm{~d}^{-1}$, respectively, lower than previously reported values (Iseki et al., 2003). The difference between two studies could be caused by different trap deployment depths, ignoring fluvial suspended matter influence from Changjiang, or different trap deployment time. While the vertical mixing model is still not a perfect model to determine sediment resuspension fluxes accurately, because it ignored biological degradation of sinking particles, terrestrial, fluvial input and lateral transport, it does result in reasonable quantitative estimates of export fluxes. It is a first step towards the development of a better model to calibrate POC flux in a highly suspended marine environment, which is needed because carbon cycling in the marginal sea is more complex than previously thought.

\section{Supplementary material related to this article is available online at http://www.biogeosciences.net/10/ 6469/2013/bg-10-6469-2013-supplement.pdf.}

Acknowledgements. We are grateful to J. Z. Tseng, W. Z. Yang, W. J. Chung, W. T. Kuo, M. L. Sheu, S. L. Lee and the crew of the R/V Ocean Research I for their assistance in collecting samples. We also thank three anonymous reviewers and the guest Editor Christophe Rabouille for giving constructive comments that improved the paper. This research was funded by grants from National Science Council (NSC100-2119-M-110-003, NSC1012611-M-110-015-MY3, NSC101-2116-M-110-001).

Edited by: C. Rabouille

\section{References}

Bale, A. J. and Morris A. W.: Organic carbon in suspended particulate material in the North Sea: effect of mixing resuspended and background particles, Cont. Shelf Res., 18, 1333-1345, 1998. 
Behrenfeld, M. J. and Falkowski, P. G.: Photosynthetic rates derived from satellite-based chlorophyll concentration, Limnol. Oceanogr., 42, 1-20, 1997.

Berelson, W. M.: Particle settling rates increase with depth in the ocean. Deep-Sea Res. Pt. II, 49, 237-251, 2002.

Bloesch, J.: A review of methods used to measure sediment resuspension. Hydrobiologia, 284, 13-18, 1994.

Bonnin, J., Raaphorst, W. v., Brummer, G. J., Haren, H. v., and Malschaert, H.: Intense mid-slope resuspension of particulate matter in the Faeroe-Shetland Channel: short-term deployment of near-bottom sediment traps, Deep-Sea Res. Pt. I., 49, 14851550, 2002.

Buesseler, K. O., Benitez-Nelson, R. R., Moran, S. B., Burd, A., Charette, M., Cochran, J. K., Coppola, L., Fisher, N. S., Fowler, S. W., Gardner, W. D., Guo, L. D., Gustafsson, O., Lamborg, C., Masque, P., Mequel, J. C., Passow, U., Santschi, P. H., Savoye, N., Stewart, G., and Trull, T.: An assessment of particulate organic carbon to thorium-234 ratios in the ocean and their impact on the application of ${ }^{234} \mathrm{Th}$ as a POC flux proxy, Mar. Chem. 100, 213-233, 2006.

Buesseler, K. O., Antia, A. N., Chen, M., Fowler, S.W., Gardner, W. D., Gustafsson, O., Harada, K., and Michaels, A. F., Rutgers van der Loeff, M., Sarin, M., Steinberg, D. K., and Trull, T.: An assessment of the use of sediment traps for estimating upper ocean particle fluxes, J. Mar. Res., 65, 345-416, 2007.

Chang, J., Shiah, F.-K., Gong, G.-C., and Chiang, K. P.: Cross-shelf variation in carbon-to-chlorophyll a ratios in the East China Sea, summer 1998, Deep-Sea Res. Pt. II, 50, 1237-1247, 2003.

Chen, C.-C., Gong, G.-C., and Shiah, F.-K.: Hypoxia in the East China Sea: one of the largest coastal low-oxygen areas in the world, Mar. Environ. Res., 64, 399-408, 2007.

Chen, C.-C., Gong, G.-C., Shiah, F.-K., Chou, W.-C., and Hung, C.-C.: The large variation in organic carbon consumption in spring in the East China Sea, Biogeosciences, 10, 2931-2943, doi:10.5194/bg-10-2931-2013, 2013.

Chen, C. T. A. and Wang, S. L.: Carbon, alkalinity and nutrient budgets on the East China Sea continental shelf, J. Geophys. Res., 104, 675-686, 1999.

Chou, W.-C., Gong, G.-C., Sheu, D.-D., Hung, C.-C., and Tseng, T.-F.: The surface distributions of carbon chemistry parameters in the East China Sea in summer 2007, J. Geophys. Res., 114, C07026, doi:10.1029/2008JC005128, 2009a.

Chou, W.-C., Gong, G.-C., Sheu, D. D., Jan, S., Hung, C.-C., and Chen, C.-C.: Reconciling the paradox that the heterotrophic waters of the East China Sea shelf act as a significant $\mathrm{CO}_{2}$ sink during the summertime: evidence and implications, Geol. Res. Lett., 35, L15607, doi:10.1029/2009GL038475, 2009b.

Chou, W.-C., Gong, G.-C., Tseng, C.-M., Sheu, D. D., Hung, C.-C., Chang, L.-P., and Wang, L.-W.: The carbonate system in the East China Sea in winter, Mar. Chem., 123, 44-55, 2011.

Chou, W.-C., Gong, G.-C., Hung, C.-C., and Wu, Y.-H.: Carbonate mineral saturation states in the East China Sea: present conditions and future scenarios, Biogeosciences, in press, 2013.

Coale, K. H. and Bruland K. W. : ${ }^{234}$ Th: ${ }^{238} \mathrm{U}$ disequilibria within the California Current, Limnol. Oceanogr., 30, 22-33, 1985.

Falkowski, P. G, Biscaye, P. E., and Sancetta, C.: The lateral flux of biogenic particles form the eastern North America continental margin to the North Atlantic Ocean, Deep-Sea Res. Pt. II, 41, 583-601, 1994.
Fang, T. H., Chen, J. L., and Huh, C. A.: Sedimentary phosphorus species and sedimentation flux in the East China Sea. Cont. Shelf Res., 27, 1465-1476, 2007.

Gardner, W. D.: Sediment trap dynamics and calibration: a laboratory evaluation, J. Mar. Res., 38, 17-39, 1980.

Gardner W. D., Hinga K. R., and Marra J. : Observations on the degradation of biogenic material in the deep ocean with implications on the accuracy of sediment trap fluxes, J. Mar. Res., 41, 195-214, 1983.

Goldstein, S. J. and Jacobsen, S. B.: Nd and Sr Isotopic Systematics of River Water Suspended Material - Implications for Crustal Evolution, Earth Planet. Sc. Lett., 87, 249-265, 1988.

Gong, G.-C., Shiah, F.-K., Liu, K.-K., Wen, Y.-H., and Liang, M.H.: Spatial and temporal variation of chlorophyll a, primary productivity and chemical hydrography in the southern East China Sea, Cont. Shelf Res., 20, 411-436, 2000.

Gong, G.-C., Wen, Y. H., Wang, B. W., and Liu, G. J.: Seasonal variation of chlorophyll $a$ concentration, primary production and environmental conditions in the subtropical East China Sea, Deep Sea Res. Pt. II, 50, 1219-1236, 2003.

Gong, G.-C., Chang, J., Chiang, K.-P., Hsiung, T.-M., Hung, C.-C., Duan, S.-W., and Codispoti, L. A.: Reduction of primary production and changing of nutrient ratio in the East China Sea: Effect of the Three Gorges Dam?, Geophys. Res. Lett. 33, L07610, doi:10.1029/2006GL025800, 2006.

Gong, G. C., Liu, K. K., Chiang, K.P., Hsiung, T.M., Chang, J., Chen, C. C., Hung, C. C., Chou, W. C., Chung, C. C., Chen, H Y., Shiah, F. K., Tsai, A.Y., Hsieh, C. H., Shiao, J. C., Tseng, C. M., Hsu, S. C., Lee, H. J., Lee, M. A., Lin, I. I., and Tsai, F., : Yangtze River floods enhance coastal ocean phytoplankton biomass and potential fish production, Geophys. Res. Lett., 38, L13603, doi:10.1029/2011GL047519, 2011.

Guo, X., and Zhang, Y.: Particle flux through the Huanghai Sea cold water mass, Acta Oceanol. Sin., 24, 78-88, 2005.

Guo, X., Zhang, Y., Zhang, F., and Cao, Q.: Characteristics and flux of settling particulate matter in neritic waters: The southern Yellow Sea and the East China Sea, Deep-Sea Res. Pt. II, 57, 10581063, 2010.

Heussner, S., de Madron, X. D., Galafat, A., Canals, M. Carbonne, J., Delsaut, N., and Saragoni, G.: Spatial and temporal variability of downward particle fluxes on a continental slope: Lessons from an 8-yr experiment in the Gulf of Lions (NW Mediterranean), Mar. Geol., 234, 63-92, 2006.

Hoshika, A., Tanimoto, T., Mishima, Y., Iseki, K., and Okamura, K.: Variation of turbidity and particle transport in the bottom layer of the East China Sea, Deep-Sea Res. Pt. II, 50, 443-455, 2003.

Hsu, S.-C. and Lin, F.-J.: Elemental characteristics of surface suspended particulates off the Changjiang estuary during the 1998 flood, J. Marine Syst., 81, 323-334, 2010.

Hung, C.-C. and Gong, G.-C.: Export flux of POC in the main stream of the Kuroshio, Geophys. Res. Lett., 34, L18606, doi:10.1029/2007GL030236, 2007.

Hung, C.-C. and Gong, G.-C.: POC $/{ }^{234}$ Th ratios in particles collected in sediment traps in the northern South China Sea, Estuar. Coast. Shelf S., 88, 303-310, 2010.

Hung, C.-C. and Gong, G.-C.: Biogeochemical responses in the southern East China Sea after typhoons, Oceanography, 24, 4251, 2011 . 
Hung, C.-C., Wong, G. T. F., Liu, K.-K., Shiah, F.-K., and Gong, G.-C.: The effects of environmental conditions on the relationship between nitrate reductase activity and ${ }^{15} \mathrm{NO}^{3-}$ uptake: field observations in the East China Sea, Limnol. Oceanogr., 45, 836848,2000

Hung, C.-C., Guo, L., Roberts, K., and Santschi, P.H.: Upper ocean carbon flux determined by ${ }^{234} \mathrm{Th}$ and sediment traps in the Gulf of Mexico, Geochem. J., 38, 601-611, 2004.

Hung, C.-C., Gong, G.-C., Chung, W.-C., Kuo, W.-T., and Lin, F.C.: Enhancement of particulate organic carbon export flux induced by atmospheric forcing in the subtropical oligotrophic northwest Pacific Ocean, Mar. Chem., 113, 19-24, 2009a.

Hung, C.-C., Gong, G.-C., Chiang, K.-P., Chen, H.-Y., and Yeager, K. M.: Particulate carbohydrates and uronic acids in the northern East China Sea. Estuar. Coast. Shelf S., 84, 565-572, 2009b.

Hung, C.-C., Gong, G.-C., Ko, F.-C., Chen, H.-Y., Hsu, M.-L., Wu, J.-M., Peng, S.-C., Nan, F.-H., Yeager, K. M., and Santschi, P. H.: Relationships between persistent organic pollutants and carbonaceous materials in aquatic sediments of Taiwan, Mar. Pollut. Bull., 60, 1010-1017, doi:10.1016/j.marpolbul.2010.01.026, 2010a.

Hung, C. C., Xu, C., Santschi, P. H., Zhang, S. J., Schwehr, K. A., Quigg, A., Guo, L. D., Gong, G. C., Pinckney, J. L., Long, R. A., and Wei, C. L.: Comparative evaluation of sediment trap and Th-234-derived POC fluxes from the upper oligotrophic waters of the Gulf of Mexico and the subtropical northwestern Pacific Ocean, Mar. Chem., 121, 132-144, 2010 b.

Hung, C.-C., Gong, G.-C., Chou, W.-C., Chung, C. -C., Lee, M.A., Chang, Y., Chen, H.-Y., Huang, S.-J., Yang, Y., Yang, W.R., Chung, W.-C., Li, S.-L., and Laws, E.: The effect of typhoon on particulate organic carbon flux in the southern East China Sea, Biogeosciences, 7, 3007-3018, doi:10.5194/bg-73007-2010, 2010c.

Hung, C.-C., Gong, G.-C., Ko, F. C., Lee, H. J., Chen, H. Y., Wu, J. M., Hsu, M. L., Peng, S. C., Nan, F. H., and Santschi, P. H.: Polycyclic aromatic hydrocarbons in surface sediments of the East China Sea and their relationship with carbonaceous materials, Mar. Pollut. Bull., 63, 464-470, 2011.

Hung, C.-C., Gong, G.-C., and Santschi, P. H.: ${ }^{234}$ Th in different size classes of sediment trap collected particles from the Northwestern Pacific Ocean, Geochim. Cosmochim. Ac., 91, 60-74, 2012.

Hung, J.-J., Lin, C. S., Hung, G. W., and Chung, Y. C.: Lateral transport of lithogenic particles from the continental margin of the southern East China Sea, Estuar. Coast. Shelf S., 49, 483-499, 1999.

Hung, J.-J., Lin, C. -S., Chung, Y.-C., Hung, G.-W., and Liu. W.-S.: Lateral fluxes of biogenic particles through the Mien-Hua canyon in the southern East China Sea slope, Cont. Shelf Res., 23, 935955, 2003

Iseki, K., Okamura, K., and Kiyomoto, Y.: Seasonality and composition of downward particulate fluxes at the continental shelf and Okinawa Trough in the East China Sea, Deep-Sea Res. Pt. II, 50, 457-473, 2003.

Jago, C. F., and Jones, S. E.: Observation and modeling of the dynamics of benthic fluff resuspended from a sandy bed in the southern North Sea, Cont. Shelf Res., 18, 1255-1282, 1998.

Jones, S. E., Jago, C. F., Bale, A. J., Chapman, D., Howland, R. M. J., and Jackson, J. J.: Aggregation and resuspension of suspended particulate matter at a seasonally stratified site in the southern North Sea: physical and biological controls, Cont. Shelf Res., 18, 1283-1309, 1998.

Kao, S. J., Lin, F. J., and Liu, K. K.: Organic carbon and nitrogen contents and their isotopic compositions in surficial sediments from the East China Sea shelf and the southern Okinawa Trough, Deep-Sea Res. Pt. II, 50, 1203-1217, 2003.

Karl, D. M. and Knauer G. A. : Swimmers, a recapitulation of the problem and a potential solution, Oceanography, 2, 32-35, 1989.

Lampitt, R. S.: Evidence for the seasonal deposition of detritus to the deep-sea floor and its subsequent resuspension, Deep-Sea Res., 32, 885-897, 1985.

Lee, H.-J. and Chao, S.-Y.: A climatological description of circulation in and around the East China Sea, Deep Sea Res. Pt. II, 50, 1065-1084, 2003.

Lee, C., Wakeham S. G., and Hedges J. I. : The measurement of oceanic particle flux - are "swimmer" a problem?, Oceanography, 1, 34-36, 1988.

Li, C.-S., Shi, X.-F., Kao, S.-J., Liu, Y.-G., Lyu, H.-H., Zou, J.-J., Liu, S.-F., and Qiao, S.-F.: Rare earth elements in fine-grained sediments of major rivers from the high-standing island of Taiwan, J. Asian Earth Sci., 69, 39-47, 2013.

Lee, H.-J. and Chao, S.-Y.: A climatological description of circulation in and around the East China Sea, Deep Sea Res. Pt. II, 50, 1065-1084, 2003.

Li, S.-L.: Particulate organic carbon flux in the upwelling region off northeastern Taiwan. Thesis, National Taiwan Ocean University, Keelung, Taiwan, 1-55, 2009.

Lin, S., Hsieh, I.-J., Huang, K.-M., and Wang, C.-H.: Influence of the Yangtze River and grain size on the spatial variations of heavy metals and organic carbon in the East China Sea continental shelf sediments, Chem. Geol., 182, 377-394, 2002.

Liu, K.-K., Iseki, K., and Chao, S. Y.: Continental margin carbon fluxes, in: The Changing Ocean Carbon, edited by: Hanson, R. B., Cycle, IGBP book series. Cambridge University Press, Cambridge, 187-239, 2000 .

Liu, K.-K., Chao, S.-Y., Marra, J., and Snidvongs, A.: Monsoonal forcing and biogeochemical environments of outer southeast asia seas, in: The sea: Ideas and observations on progress in the study of seas, vol. 14, the global coastal ocean: Interdisciplinary regional studies and synthesis, edited by: Robinson, A. and Brink, K. H., Harvard Univ. Press, Cambridge, 673-721, 2006.

Liu, K.-K., Gong, G.-C., Wu, C.-R., Lee, H.-J., and Lee, B.-S.: Biogeochemistry of the Kuroshio and the East China Sea, in: Carbon and nutrient fluxes in continental margins: a global synthesis, edited by: Liu, K.-K., Atkinson, L., Quinones, R., and TalaueMcManus, L., IGBP Book Series, Springer, 2010.

Marty, J. C., Goutx, M., Guigue, C., Leblond, N., and Raimbault, P.: Short-term changes in particulate fluxes measured by drifting sediment traps during end summer oligotrophic regime in the NW Mediterranean Sea, Biogeosciences, 6, 887-899, doi:10.5194/bg-6-887-2009, 2009.

McLennan, S. M.: Rare earth elements in sedimentary rocks: influene of provenance and sedimentary processes, in: Geochemistry and Mineralogy of Rare Earth Elements, edited by: Lipin, B. R. and McKay, G. A., Reviews in Mineralogy, vol 21., Mineralogy Society of America, Washington, DC, 169-200, 1989.

Morris, A. W., Bale, A. J., Howland, R. J. M., Loring, D. H., and Rantala, R. T. T.: Controls of the chemical composition of par- 
ticle populations in a macrotidal estuary (Tamar Estuary, U.K.), Cont. Shelf Res., 7, 1351-1355, 1987.

Oguri, K., Matsumoto, E., Yamada, M., Saito, Y., and Iseki, K.: Sediment accumulation rates and budgets of depositing particles of the East China Sea, Deep-Sea Res. Pt. II, 50, 513-528, 2003.

Parsons, T. R., Maita, Y., Lalli, C. M.: A manual of chemical and biological methods for seawater analysis, Pergamon Press, Oxford, 173 pp., 1984.

Peng, T.-H., Hung, J.-J., Wanninkhof, R., and Millero, F. J.: Carbon budget in the East China Sea in spring, Tellus B, 51, 531-540, 1999.

Rosa, F.: Sedimentation and sediment resuspension in lake ontario, J. Great Lakes Res., 11, 13-25, 1985.

Santschi, P. H., Hung, C.-C., Guo, L., Schultz, G. G., Pinckney, J., and Walsh, I.: Control of acid polysaccharide production, ${ }^{234} \mathrm{Th}$ and particulate organic carbon export flux by marine organisms, Geophys. Res. Lett., 30, 1044, doi:10.1029/2002GL015727, 2003.

Santschi, P. H., Murray, J. W., Baskaran, M., Benitez-Nelson, C., Guo, L. D., Hung, C.-C., Lamborg, C., Moran, S. B., Passow, U., and Roy-Barman, M.: Thorium speciation in seawater, Mar. Chem., 100, 250-268, 2006.

Sheu, D. D., Jou, W.-C., Chen, M.-J., Lee, W.-Y., and Lin, S.: Variations of calcium carbonate, organic carbon and their isotopic compositions in surface sediments of the East China Sea, Terr. Atmos. Ocean. Sci., 6, 115-128, 1995.

Shih, Y.-Y., Hsieh, J.-S., Gong, G.-C., Hung, C.-C., Chou, W.-C., Lee, M.-A., Chen, K.-S., Chen, M.-H., and Wu, C.-R.: Field observations of changes in SST, chlorophyll and POC flux in the southern East China Sea before and after the passage of Typhoon Jangmi, Terr. Atmos. Ocean. Sci., 24, 899-910, 2013.

Shim, J., Kim, D., Kang, Y. C., Lee, J. H., Jang, S.-T., and Kim, C.-H.: Seasonal variations in $p \mathrm{CO}_{2}$ and its controlling factors in surface seawater of the northern East China Sea, Cont. Shelf Res., 27, 2623-2636, 2007.

Sholkovitz, E. R., Elderfield, H., Szymczak, R., and Casey, K.: Island weathering: river sources of rare earth elements to the Western Pacific Ocean, Mar. Chem., 68, 39-57, 1999.

Siswanto, E., Morimoto, A., and Kojima, S.: Enhancement of phytoplankton primary productivity in the southern East China Sea following episodic typhoon passage, Geophys. Res. Lett., 36, L11603, doi:10.1029/2009GL037883, 2009.
Smith, S. V. and Hollibaugh, J. T.: Coastal metabolism and the oceanic carbon balance, Rev. Geophys., 31, 75-89, 1993.

Tsai, C. H.: An assessment of a time-of-transition laser size in measuring suspended particles in the ocean, Mar. Geol., 134, 85-112, 1996.

Tseng, C. W.: Summer particulate organic carbon flux in the East China Sea. Thesis, National Taiwan Ocean University, Keelung, Taiwan, 1-43, 2010.

Tsunogai, S., Watanabe, S., and Sato, S. T.: Is there a "continental shelf pump" for the absorption of atmospheric $\mathrm{CO}_{2}$ ?, Tellus $\mathrm{B}$, 51, 701-712, 1999.

Walsh, J. J.: How much shelf production reaches the deep sea?, in: Productivity of the Ocean: Present and Past, edited by: Berger, W. H., Smetacek, V. S., and Wefer, G., 175-191, New York, Wiley, 1989.

Wang, B.: Hydromorphologiccal mechanisms leading to hypoxia off the Changjiang estuary, Mar. Environ. Res., 67, 53-58, 2009.

Wang, S. L., Chen, C. T. A., Hong, G. H., and Chung, C. S.: Carbon dioxide and related parameters in the East China Sea, Cont. Shelf Res., 20, 525-544, 2000.

Wei, C.-L., Lin, S.-Y., Sheu, D. D.-D., Chou, W.-C., Yi, M.-C., Santschi, P. H., and Wen, L.-S.: Particle-reactive radionuclides $\left({ }^{234} \mathrm{Th},{ }^{210} \mathrm{~Pb},{ }^{210}\right)$ as tracers for the estimation of export production in the South China Sea, Biogeosciences, 8, 3793-3808, doi:10.5194/bg-8-3793-2011, 2011.

Xu, C., Santschi, P.H., Hung, C.-C., Zhang, S., Schwehr, K. A., Roberts, K. A., Guo, L., Gong, G.-C., Quigg, A., Long, R. A., Pinckney, J. L., Duan, S., Amon, R., and Wei, C.-L.: Controls of ${ }^{234} \mathrm{Th}$ removal from the oligotrophic ocean by polyuronic acids and modification by microbial activity, Mar. Chem., 123, 111126, 2011.

Zhang, G., Wang, L., Zhang, S., and Li, X.: Geochemistry of rate earth elements in the mainstream of the Yangtze River, China, Appl. Geochem., 12, 451-462, 1998.

Zhu, Z.-Y., Zhang, J., Wu, Y., and Lin J.: Bulk particulate organic carbon in the East China Sea: Tidal influence and bottom transport, Prog. Oceanogr., 69, 37-60, 2006.

Zhu, Z.-Y., Zhang, J., Wu, Y., Zhang, Y.-Y., Lin, J., and Liu, S.M.: Hypoxia off the Changjiang (Yangtze River) estuary: oxygen depletion and organic matter decomposition, Mar. Chem., 125, 108-116, 2011. 